\title{
Transformations of lead 1,3-propylenediaminetetraacetate to its MOF products for the selective adsorption of methanol
}

Jun-Wei Dai, Xing Li, Jian-Mei Zheng, Xin Dong,* Zhao-Hui Zhou*

College of Chemistry and Chemical Engineering, State Key Laboratory of Physical Chemistry of Solid Surfaces, Xiamen University, Xiamen 361005, China

\begin{abstract}
Water soluble coordination polymer of potassium lead 1,3-propylenediaminetetraacetate $\left\{\mathrm{K}_{4}\left[\mathrm{~Pb}_{2}(1,3-\text { pdta })_{2}\right] \cdot 6 \mathrm{H}_{2} \mathrm{O}\right\}_{\mathrm{n}}(\mathbf{1})$ and its insoluble products $\left\{\left[\mathrm{Pb}\left(1,3-\mathrm{H}_{2} \text { pdta }\right)\left(\mathrm{H}_{2} \mathrm{O}\right)\right] \cdot 2 \mathrm{H}_{2} \mathrm{O}\right\}_{\mathrm{n}}$ (2), $\left\{\left[\mathrm{Pb}_{2}(1,3-\text { pdta })\left(\mathrm{H}_{2} \mathrm{O}\right)_{4}\right] \cdot 4 \mathrm{H}_{2} \mathrm{O}\right\}_{\mathrm{n}}(3)$ and $\left[\mathrm{Pb}_{2}(1,3-\text { pdta })\left(\mathrm{H}_{2} \mathrm{O}\right)_{2}\right]_{\mathrm{n}}$ (4) were obtained from the direct reactions of lead nitrate with 1,3-propylenediaminetetraacetic acid in different conditions $\left(1,3-\mathrm{H}_{4}\right.$ pdta $=1,3$-propylenediaminetetraacetic acid). The former $\mathbf{1}$ could be converted to the insoluble products of $\left\{\left[\mathrm{Pb}_{2}(1,3-\text { pdta })\left(\mathrm{H}_{2} \mathrm{O}\right)_{4}\right] \cdot 4 \mathrm{H}_{2} \mathrm{O}\right\}_{\mathrm{n}} \quad$ (3) and $\left[\mathrm{Pb}_{2}(1,3 \text {-pdta })\left(\mathrm{H}_{2} \mathrm{O}\right)_{2}\right]_{\mathrm{n}}$ (4) in weak acidic solution. The complexes have been full characterized by EA, FT-IR, solution and solid state ${ }^{13} \mathrm{C}$ NMR spectra, thermogravimetric and structural analyses. Interestingly, 3 contains a unique $\left(\mathrm{H}_{2} \mathrm{O}\right)_{26}$ cluster and a $5.2 \AA$ pore after eliminating the guest water molecules, which exhibits reversible adsorption for methanol. This is confirmed by PXRD and solid state ${ }^{13} \mathrm{C}$ NMR analyses. Nano-confined methanol in microporous structure has been observed based on the large downfield shift of ${ }^{13} \mathrm{C}$ NMR signal ( $\Delta \delta 9.72 \mathrm{ppm})$, attributing to the methyl group in methanol.
\end{abstract}

Keywords: Lead; 1,3-Propylenediaminetetraacetic acid; MOF structures; Solid state NMR; Adsorption; Methanol 
* Corresponding authors. Tel.: +86 592 2184531; fax: +86 5922183047.

E-mail address: dxin@xmu.edu.cn, zhzhou@xmu.edu.cn (Z.-H. Zhou). 


\section{Introduction}

Lead has important applications in paint and battery industries [1-3]. It is also a heavy metal pollutant that widely exists in our environment [4,5]. Lead may poison human bodies by combining with nucleic acid, protein and cell membrane thiol or phosphoric acid. Presently, the most ideal lead's antidote should be ethylenediaminetetraacetic acid $\left(\mathrm{H}_{4} \mathrm{edta}\right)$ due to its high stability constant when coordinates with lead ions and excellent water-solubility [6]. As a derivative of ethylenediaminetetraacetic acid, 1,3-propanediaminetetraacetic acid (1,3- $\left.\mathrm{H}_{4} \mathrm{pdta}\right)$ is also a tetrabasic acid with eight potential O-donor and two N-donor atoms. It has similar coordination ability with ethylenediaminetetraacetic acid. However, the 1,3- $\mathrm{H}_{4}$ pdta can form a more flexible chelating ring due to the longer diamine chain when employed as a multidentate ligand. Up to now, a series of isolated chelates such as, $\left.\mathrm{M}^{\prime}\left(\mathrm{H}_{2} \mathrm{O}\right)_{6}\right][\mathrm{M}(1,3-$ pdta $)] \cdot 2 \mathrm{H}_{2} \mathrm{O}(\mathrm{M}=$ $\mathrm{Mg}$ [7], $\mathrm{Co} \quad[8,9], \quad \mathrm{Ni} \quad[10,11], \quad \mathrm{Cu} \quad[10,12,13]$ and $\mathrm{Zn} \quad[14]), \quad\left[\mathrm{M}^{\prime}\left(\mathrm{H}_{2} \mathrm{O}\right)_{6}\right]$ $\left[\mathrm{M}(1,3-\right.$ pdta $\left.)\left(\mathrm{H}_{2} \mathrm{O}\right)\right] \cdot 2 \mathrm{H}_{2} \mathrm{O}(\mathrm{M}=\mathrm{Mn}[15]$ and $\mathrm{Cd}[14,15])$, and 1D chain-like coordination polymers $\left[\mathrm{Ca}\left(\mathrm{H}_{2} \mathrm{O}\right)_{3}\right]\left[\mathrm{Ca}(1,3-\right.$ pdta $\left.)\left(\mathrm{H}_{2} \mathrm{O}\right)\right] \cdot 2 \mathrm{H}_{2} \mathrm{O} \quad[7], \quad\left[\mathrm{Ba}\left(1,3-\mathrm{H}_{2} \text { pdta }\right)\left(\mathrm{H}_{2} \mathrm{O}\right)\right]_{\mathrm{n}} \quad[16]$ and $\left[\mathrm{ZnCl}_{2}\left(1,3-\mathrm{H}_{2} \mathrm{pdta}\right) \mathrm{ZnCl}_{2}\right]_{\mathrm{n}}$ [17] and La-1,3-pdta with MOF structure [18,19] have been isolated using 1,3-pdta ligand. However, less concern is related to the isolations of the lead chelate. Here lead 1,3-propylenediaminetetraacetates $\left\{\mathrm{K}_{4}\left[\mathrm{~Pb}_{2}(1,3-\mathrm{pdta})_{2}\right] \cdot 6 \mathrm{H}_{2} \mathrm{O}\right\}_{\mathrm{n}} \quad(\mathbf{1})$, $\left\{\left[\mathrm{Pb}\left(1,3-\mathrm{H}_{2} \text { pdta }\right)\left(\mathrm{H}_{2} \mathrm{O}\right)\right] \cdot 2 \mathrm{H}_{2} \mathrm{O}\right\}_{\mathrm{n}} \quad$ (2), $\quad\left\{\left[\mathrm{Pb}_{2}(1,3-\text { pdta })\left(\mathrm{H}_{2} \mathrm{O}\right)_{4}\right] \cdot 4 \mathrm{H}_{2} \mathrm{O}\right\}_{\mathrm{n}} \quad$ (3) $\quad$ and $\left[\mathrm{Pb}_{2}(1,3-\text { pdta })\left(\mathrm{H}_{2} \mathrm{O}\right)_{2}\right]_{\mathrm{n}}$ (4) have been prepared and full characterized. It is notable that $\mathbf{1}$ is well water-soluble which is similar to lead ethylenediaminetetraacetates, and could be converted to the insoluble products of $\mathbf{3}$ and $\mathbf{4}$. Interestingly, $\mathbf{3}$ contains a unique $\left(\mathrm{H}_{2} \mathrm{O}\right)_{26}$ cluster and an open-channel structure with a $5.2 \AA$ pore. Although there are many MOFs products which can be used for gas absorption like $\mathrm{H}_{2}, \mathrm{~N}_{2}, \mathrm{CO}_{2}$ reported [20-24], there are relatively few examples of MOFs that can selectively adsorb liquid molecules. [18,25-27]. In this contribution, the reversible adsorption and desorption of methanol using MOF $\mathbf{3}$ are 
demonstrated and confirmed by PXRD and solid state ${ }^{13} \mathrm{C}$ NMR analyses.

\section{Experimental}

\subsection{Materials and physical techniques}

All chemical reagents were analytic grade. Elemental analyses $(\mathrm{C}, \mathrm{H}$ and $\mathrm{N})$ were performed on a Vario EL III CHN elemental analyzer, and the ammonium-N was determined by ion chromatography. IR spectra were recorded in the range $400 \sim 4000 \mathrm{~cm}^{-1}$ on a Nicolet FT-IR 330 spectrometer in KBr pellets. TG analyses were performed on a Netzsch SDT Q600 instrument in air atmosphere with a heating rate of $10{ }^{\circ} \mathrm{C} \cdot \mathrm{min}^{-1}$. Solid state ${ }^{13} \mathrm{C}$ NMR spectra were recorded on a Bruker AV 400 NMR spectrometer using cross polarization, magic angle spinning $(13 \mathrm{kHz})$ and adamantane as the reference. Solution ${ }^{13} \mathrm{C}$ NMR spectra were recorded on a Bruker AV 400 NMR spectrometer in $\mathrm{D}_{2} \mathrm{O}$ using DSS (sodium 2,2-dimethyl-2-silapentane-5-sulfonate) as the internal reference. Gas chromatography was performed on a Shimadzu GC-2010 instrument equipped with a flame ionization detector (FID) and an OV-17 column.

\subsection{Synthesis of $\left\{\mathrm{K}_{4}\left[\mathrm{~Pb}_{2}(1,3-p d t a)_{2}\right] \cdot 6 \mathrm{H}_{2} \mathrm{O}\right\}_{n}(1)$.}

1,3- $\mathrm{H}_{4}$ pdta $(306 \mathrm{mg}, 1.0 \mathrm{mmol})$ and $\mathrm{Pb}\left(\mathrm{NO}_{3}\right)_{2}(331 \mathrm{mg}, 1.0 \mathrm{mmol})$ was dissolved in water $(1.0 \mathrm{~mL})$. The $\mathrm{pH}$ value of the mixture was adjusted to 9.0 with $2.0 \mathrm{M} \mathrm{KOH}$. The solution was added with $10 \mathrm{~mL}$ methanol and stirred for $15 \mathrm{~min}$ at room temperature, and warmed at $80{ }^{\circ} \mathrm{C}$ for $18 \mathrm{~h}$. The mixture was allowed to evaporate at room temperature. After one day, colorless acicular crystals of 1 were isolated with a yield of $180 \mathrm{mg}$ (28.1\%). Anal. calcd. for $\mathrm{C}_{22} \mathrm{H}_{40} \mathrm{~N}_{4} \mathrm{O}_{22} \mathrm{~Pb}_{2} \mathrm{~K}_{4}$ (Mr 1283.36): C, 20.6; H, 3.1; N, 4.4; found: C, 20.4; H, 3.1; N, 4.5. IR $\left(\mathrm{cm}^{-1}\right): 3362_{\mathrm{sb}}, 2856_{\mathrm{w}}, 1583_{\mathrm{s}}, 1393_{\mathrm{s}}, 1332_{\mathrm{m}}, 1256_{\mathrm{w}}, 705_{\mathrm{w}}, 629_{\mathrm{w}}, 557_{\mathrm{w}}$.

2.2. Synthesis of $\left\{\left[\mathrm{Pb}\left(1,3-\mathrm{H}_{2} \mathrm{pdta}\right)\left(\mathrm{H}_{2} \mathrm{O}\right)\right] \cdot 2 \mathrm{H}_{2} \mathrm{O}\right\}_{n}(2)$.

1,3- $\mathrm{H}_{4}$ pdta $(612 \mathrm{mg}, 2.0 \mathrm{mmol})$ was dissolved in $10 \mathrm{~mL}$ water. A solution of $\mathrm{Pb}\left(\mathrm{NO}_{3}\right)_{2}$ 
(662 $\mathrm{mg}, 2.0 \mathrm{mmol}$ ) in $5 \mathrm{~mL}$ water were added to the above solution. The $\mathrm{pH}$ value of the mixture was adjusted to 3.0 with $2.0 \mathrm{M} \mathrm{KOH}$. The solution was stirred for $15 \mathrm{~min}$ at room temperature and warmed at $80{ }^{\circ} \mathrm{C}$ for $18 \mathrm{~h}$ and filtered. The filtrate was allowed to evaporate at room temperature. After one week, colorless bulk crystals of $\mathbf{2}$ were isolated with a yield of $313 \mathrm{mg}\left(27.6 \%\right.$ ). Anal. calcd. for $\mathrm{C}_{11} \mathrm{H}_{20} \mathrm{~N}_{2} \mathrm{O}_{11} \mathrm{~Pb}(\mathrm{Mr}$ 565.50): C, 23.4; H, 3.6; N, 5.0; found: C, 23.0; H, 3.8; N, 4.9. IR ( $\left.\mathrm{cm}^{-1}\right): 3440_{\mathrm{sb}}, 3021_{\mathrm{m}}, 1627_{\mathrm{s}}, 1396_{\mathrm{s}}, 1322_{\mathrm{m}}, 922_{\mathrm{w}}, 706_{\mathrm{w}}, 540_{\mathrm{w}}$. 2.3. Synthesis of $\left\{\left[\mathrm{Pb}_{2}(1,3-p d t a)\left(\mathrm{H}_{2} \mathrm{O}\right)_{4}\right] \cdot 4 \mathrm{H}_{2} \mathrm{O}\right\}_{n}(3)$.

1,3- $\mathrm{H}_{4}$ pdta $(612 \mathrm{mg}, 2.0 \mathrm{mmol})$ was dissolved in $10 \mathrm{~mL}$ water. A solution of $\mathrm{Pb}\left(\mathrm{NO}_{3}\right)_{2}$ (331 mg, $1.0 \mathrm{mmol}$ ) in $5 \mathrm{~mL}$ water were added. The $\mathrm{pH}$ value was adjusted to 4.0 with $2.0 \mathrm{M}$ $\mathrm{KOH}$. The mixture was stirred for $15 \mathrm{~min}$ at room temperature, and warmed at $80{ }^{\circ} \mathrm{C}$ for $18 \mathrm{~h}$. The solution was allowed to evaporate at room temperature. After one day, colorless acicular crystals of $\mathbf{3}$ were isolated with a yield of $394 \mathrm{mg}$ ( $91.5 \%$ based on lead nitrate). Anal. calcd. for $\mathrm{C}_{11} \mathrm{H}_{30} \mathrm{~N}_{2} \mathrm{O}_{16} \mathrm{~Pb}_{2}(\mathrm{Mr}$ 860.75): $\mathrm{C}, 15.3 ; \mathrm{H}, 3.5 ; \mathrm{N}, 3.3$; found: $\mathrm{C}, 15.0 ; \mathrm{H}, 3.6 ; \mathrm{N}, 3.5$. IR $\left(\mathrm{cm}^{-1}\right): 3446_{\mathrm{sb}}, 1587_{\mathrm{s}}, 1400_{\mathrm{m}}, 620_{\mathrm{w}}, 483_{\mathrm{w}}$.

2.4. Synthesis of $\left[\mathrm{Pb}_{2}(1,3-p d t a)\left(\mathrm{H}_{2} \mathrm{O}\right)_{2}\right]_{n}(4)$.

1,3- $\mathrm{H}_{4}$ pdta $(306 \mathrm{mg}, 1.0 \mathrm{mmol})$ was dissolved into $10 \mathrm{~mL}$ water. A solution of $\mathrm{Pb}\left(\mathrm{NO}_{3}\right)_{2}(331 \mathrm{mg}, 1.0 \mathrm{mmol})$ in $5 \mathrm{~mL}$ water were added. The $\mathrm{pH}$ value was adjusted to 5.0 with a 2.0 M KOH solution. The mixture was stirred for $15 \mathrm{~min}$ at room temperature, and warmed at $80{ }^{\circ} \mathrm{C}$ for $18 \mathrm{~h}$. The solution was allowed to evaporate at room temperature. After one week, colorless bulk crystals of 4 were isolated with a yield of $295 \mathrm{mg}$ (78.4\%). Anal. calcd. for $\mathrm{C}_{11} \mathrm{H}_{18} \mathrm{~N}_{2} \mathrm{O}_{10} \mathrm{~Pb}_{2}(\mathrm{Mr}$ 752.65): C, 17.5; H, 2.4; N, 3.7; found: C, 17.0; H, 2.4; N, 3.6. IR $\left(\mathrm{cm}^{-1}\right): 3441_{\mathrm{sb}}, 2925_{\mathrm{w}}, 1585_{\mathrm{s}}, 1376_{\mathrm{m}}, 1111_{\mathrm{w}}, 712_{\mathrm{w}}, 620 \mathrm{w}, 538_{\mathrm{w}}$.

2.5. Conversions of $\left\{\mathrm{K}_{4}\left[\mathrm{~Pb}_{2}(1,3-p d t a)_{2}\right] \cdot 6 \mathrm{H}_{2} \mathrm{O}\right\}_{n}$ (1) to $\left\{\left[\mathrm{Pb}_{2}(1,3-p d t a)\left(\mathrm{H}_{2} \mathrm{O}\right)_{4}\right] \cdot 4 \mathrm{H}_{2} \mathrm{O}\right\}_{n}$ (3) and $\left[\mathrm{Pb}_{2}(1,3-\mathrm{pdta})\left(\mathrm{H}_{2} \mathrm{O}\right)_{2}\right]_{n}(4)$.

$\left\{\mathrm{K}_{4}\left[\mathrm{~Pb}_{2}(1,3-\mathrm{pdta})_{2}\right] \cdot 6 \mathrm{H}_{2} \mathrm{O}\right\}_{\mathrm{n}}(\mathbf{1})(80 \mathrm{mg}, 62.5 \mu \mathrm{mol})$ was dissolved into $2 \mathrm{~mL}$ water. The 
$\mathrm{pH}$ value was adjusted to 4.0 with a $2.0 \mathrm{M} \mathrm{HCl}$ solution and warmed at $80{ }^{\circ} \mathrm{C}$ for $18 \mathrm{~h}$. The solution was allowed to evaporate at room temperature. After one day, colorless acicular crystals of 3 were isolated with a yield of $49 \mathrm{mg}(91.1 \%)$.

$$
\left\{\mathrm{K}_{4}\left[\mathrm{~Pb}_{2}(1,3-\text { pdta })_{2}\right] \cdot 6 \mathrm{H}_{2} \mathrm{O}\right\}_{\mathrm{n}}(\mathbf{1}) \quad(80 \mathrm{mg}, 62.5 \mu \mathrm{mol}) \text { and } \mathrm{Pb}\left(\mathrm{NO}_{3}\right)_{2}(41 \mathrm{mg}, 0.125 \mathrm{mmol})
$$
was dissolved into $10 \mathrm{~mL}$ water. The $\mathrm{pH}$ value was adjusted to 5.0 and warmed at $80{ }^{\circ} \mathrm{C}$ for $18 \mathrm{~h}$. The solution was allowed to evaporate at room temperature. After three days, colorless bulk crystals of 4 were isolated with a yield of $39 \mathrm{mg}(41.4 \%)$.

\subsection{Adsorption and desorption experiments of $\left\{\left[\mathrm{Pb}_{2}(1,3-p d t a)\left(\mathrm{H}_{2} \mathrm{O}\right)_{4}\right] \cdot 4 \mathrm{H}_{2} \mathrm{O}\right\}_{n}(3)$.}

$\left\{\left[\mathrm{Pb}_{2}(1,3-\text { pdta })\left(\mathrm{H}_{2} \mathrm{O}\right)_{4}\right] \cdot 4 \mathrm{H}_{2} \mathrm{O}\right\}_{\mathrm{n}}(3)(215 \mathrm{mg}, 0.25 \mathrm{mmol})$ was immersed in $10 \mathrm{~mL} \mathrm{1:1}$ methanol-ethanol solution for 5 mins to demonstrate the selective adsorption of methanol over ethanol. The solids were filtered and used for solid ${ }^{13} \mathrm{C}$ NMR, PXRD analyses. Then the solids were warmed at $60{ }^{\circ} \mathrm{C}$ for $1 \mathrm{~h}$ to release methanol and immersed in water for $6 \mathrm{~h}$ to reabsorb water molecules. The resulted solid was used for ${ }^{13} \mathrm{C}$ NMR and PXRD measurements.

$\left\{\left[\mathrm{Pb}_{2}(1,3-\text { pdta })\left(\mathrm{H}_{2} \mathrm{O}\right)_{4}\right] \cdot 4 \mathrm{H}_{2} \mathrm{O}\right\}_{\mathrm{n}}(3)(86 \mathrm{mg}, 0.10 \mathrm{mmol})$ was immersed in ethanol (10 $\mathrm{mL}$ ) for one week. The crystals were used for structural analyses on an Oxford CCD diffractometer. The result demonstrates that ethanol has no affinity for adsorption into 3 .

2.7. The measurement of absorbed methanol in $\left\{\left[\mathrm{Pb}_{2}(1,3-\mathrm{pdta})\left(\mathrm{H}_{2} \mathrm{O}\right)_{4}\right] \cdot 4 \mathrm{H}_{2} \mathrm{O}\right\}_{n}(3)$.

$\left\{\left[\mathrm{Pb}_{2}(1,3-\mathrm{pdta})\left(\mathrm{H}_{2} \mathrm{O}\right)_{4}\right] \cdot 4 \mathrm{H}_{2} \mathrm{O}\right\}_{\mathrm{n}}(3)(860 \mathrm{mg}, 1.0 \mathrm{mmol})$ were immersed in $2 \mathrm{~mL}$ methanol solution overnight. The solids were filtered and immersed in $1.0 \mathrm{~mL}$ acetone for 2 hours to extract methanol. The filtrate was analyzed by gas chromatography to calculate the relative amount of methanol absorbed for 3 .

\subsection{X-ray structural analyses}

Crystals with suitable size were sealed in capillaries. The X-ray diffraction data of $\mathbf{1}$ 4 were collected on an Oxford CCD diffractometer with graphite monochromatic Mo-K $\alpha$ 
radiation $(\lambda=0.71073 \AA)$ at $173(2) \mathrm{K}$. Multi-scan absorption corrections were applied. The structures were solved with direct method and refined by full-matrix least squares on $\mathrm{F}^{2}$ using SHELXTL software package [28-30]. The hydrogen atoms on the carbon atoms were added theoretically. Summaries of the crystallography data and refinements for $\mathbf{1} \sim \mathbf{4}$ are listed in Table S1. CCDC deposition numbers are 1433509 (1), 1418097 (2), 1418474 (3), 1418099 (4) respectively.

\section{Results and discussion}

In the synthesis, $\mathrm{pH}$ values, concentrations and the molar ratios of reactants are crucial factors for the formation of products. Unlike the water soluble lead ethylenediaminetetraacetate obtained in neutral solution [31]. lead propylenediaminetetraacetate $\mathbf{1}$ was isolated in a basic solution. The lower solubility of reagents in methanol resulted in the formation of $\mathbf{1}$, while $\mathbf{2} \sim \mathbf{4}$ were obtained in weakly acidic solutions. Higher concentration of reactants and lower $\mathrm{pH}$ value may induce the formation of tertiary ammonium salt $\left\{\left[\mathrm{Pb}\left(1,3-\mathrm{H}_{2} \text { pdta }\right)\left(\mathrm{H}_{2} \mathrm{O}\right)\right] \cdot 2 \mathrm{H}_{2} \mathrm{O}\right\}_{\mathrm{n}}$ (2). 1, 2 and $\mathbf{4}$ are obtained with $1: 1$ molar ratio of $\mathrm{Pb}^{2+}: 1,3$-pdta. However, 3 could be obtained in a high yield with excess ligand for 1:2 molar ratio of $\mathrm{Pb}^{2+}: 1,3$-pdta. Its optimal $\mathrm{pH}$ value is $3.0 \sim 4.0$.

Complex $\mathbf{1}$ is very soluble in water and could be served as a starting material for the preparations of 3 and $\mathbf{4}$. Complexes $2 \sim 4$ are insoluble in water or organic solvents. The conversions of $\mathbf{1}$ to $\mathbf{3}$ and $\mathbf{4}$ are shown in Scheme 1.

[Scheme 1]

\subsection{Crystal structures of $\mathbf{1} \sim \mathbf{4}$}

The structural frameworks of the complexes are constructed by $\mathrm{Pb}$ (II) ions and 
1,3-pdta ligands with various coordination modes. In 1, 1,3-pdta acts as a chelate ligand and forms one dimensional chain. When the nitrogen-atoms of 1,3-pdta ligand was not coordinated, two dimensional bilayer networks were constructed in $\mathbf{2}$. In $\mathbf{3}$ and 4, 1,3-pdtas acted as bridged bis-tridentate ligand and formed three dimensional frameworks.

\subsubsection{Structure of $\left\{\mathrm{K}_{4}\left[\mathrm{~Pb}_{2}(1,3-p d t a)_{2}\right] \cdot 6 \mathrm{H}_{2} \mathrm{O}\right\}_{n}(\mathbf{1})$.}

Structure of $\left\{\mathrm{K}_{4}\left[\mathrm{~Pb}_{2}(1,3-\text { pdta })_{2}\right] \cdot 6 \mathrm{H}_{2} \mathrm{O}\right\}_{\mathrm{n}}(\mathbf{1})$ comprises a dimeric unit as shown in Figure 1, which contains two centrosymmetric mononuclear chelated units. $\mathrm{Pb}$ (II) ion exists in octadentate coordination environment with two nitrogen atoms and four oxygen atoms from 1,3-pdta, forming mononuclear unit. Two mononuclear chelated units connected each other by $\mathrm{Pb}(1)-\mathrm{O}(2 \mathrm{a})$ and $\mathrm{Pb}(1 \mathrm{a})-\mathrm{O}(2)$ to make up a dimeric unit, which is further bridged by $\mathrm{O}(7)$ into an infinite chain (Figure S1).The distance between the two chains is 13.355(4) $\AA$.

\section{[Figure 1]}

\subsubsection{Structure of $\left\{\left[\mathrm{Pb}\left(1,3-\mathrm{H}_{2} \mathrm{pdta}\right)\left(\mathrm{H}_{2} \mathrm{O}\right)\right] \cdot 2 \mathrm{H}_{2} \mathrm{O}\right\}_{\mathrm{n}}(2)$}

Structure of $\left\{\left[\mathrm{Pb}\left(1,3-\mathrm{H}_{2} \mathrm{pdta}\right)\left(\mathrm{H}_{2} \mathrm{O}\right)\right] \cdot 2 \mathrm{H}_{2} \mathrm{O}\right\}_{\mathrm{n}}(2)$ comprises a $2 \mathrm{D}$ bilayer structure as shown in Figures $\mathrm{S} 2 \mathrm{a}$ and $\mathrm{S} 2 \mathrm{~b}$. In an asymmetric unit, the coordination environment of $\mathrm{Pb}(\mathrm{II})$ ion is fulfilled by seven carboxyl oxygen atoms from four 1,3-pdta ligands and one water molecules which formed $\mathrm{PbO}_{8}$ polyhedron as shown in Figure 2. There is no coordination for protonated nitrogen atoms in 1,3-pdta. The 1,3-pdta uses three of its four carboxyl groups to coordinate with three $\mathrm{Pb}(\mathrm{II})$ ions respectively, which bridges the network into an infinite 2D layer as shown in Figure S2a. It still uses one carboxyl oxygen atoms $\mathrm{O}(7)$ to connect adjacent layer by weakly coordinated to the other $\mathrm{Pb}$ (II) ion, which formed a bilayer structure as shown in Figure S2b. There is a $2.7 \AA$ micropore constructed by two 1,3-pdtas and two $\mathrm{Pb}(\mathrm{II})$ atoms. After removing guest water molecules it leaves a 9.6\% solvent accessible VOID calculated by PLATON [32].

If considered the $\mathrm{Pb}$ (II) ions and 1,3-pdta as nodes in topology, both $\mathrm{Pb}$ and ligands in 2 are 
4-connected which simplified the $2 \mathrm{D}$ bilayers structure into a 4-connected uninodal SP-type of 2-periodic net topological motif with a Schlafli symbol of $\left(4^{3} \cdot 6^{3}\right)$ as shown in Figure S2c.

[Figure 2]

\subsubsection{Structure of $\left\{\left[\mathrm{Pb}_{2}(1,3-\text { pdta })\left(\mathrm{H}_{2} \mathrm{O}\right)_{4}\right] \cdot 4 \mathrm{H}_{2} \mathrm{O}\right\}_{n}(3)$}

Structure of $\left\{\left[\mathrm{Pb}_{2}(1,3-\mathrm{pdta})\left(\mathrm{H}_{2} \mathrm{O}\right)_{4}\right] \cdot 4 \mathrm{H}_{2} \mathrm{O}\right\}_{\mathrm{n}}$ (3) comprises a three-dimensional polymeric network, where lead atoms are bridged by 1,3-pdta ligands (Figure 3b). A dinuclear structure forms the asymmetric unit (Figure 3a). There are two different coordination environments for the two $\mathrm{Pb}(\mathrm{II})$ ions. $\mathrm{Pb}(1)$ exists in octadentate coordination environment, which contains one nitrogen atom, five carboxyl oxygen atoms from three different 1,3-pdta ligands and two water molecules. $\mathrm{Pb}(2)$ exists in nonadentate coordination environment, which contains one nitrogen atom, six carboxyl oxygen atoms from three different 1,3-pdta ligands and two water molecules. Two $\mathrm{Pb}(\mathrm{II})$ ions share one 1,3-pdta ligand building the dinuclear unit.

Each 1,3-pdta ligand acts as bridge in the 3D structure by connecting $\mathrm{Pb}$ (II) ions. it chelates two $\mathrm{Pb}(\mathrm{II})$ ions by two tridentate aminodicarboxyl groups $[\mathrm{N}(1), \mathrm{O}(1), \mathrm{O}(3)$ and $\mathrm{N}(2)$, $\mathrm{O}(5), \mathrm{O}(7)]$. At the same time, it uses three carboxyl groups $[\mathrm{O}(1)-\mathrm{C}(1)-\mathrm{O}(2)$, $\mathrm{O}(5)-\mathrm{C}(5)-\mathrm{O}(6), \mathrm{O}(7)-\mathrm{C}(7)-\mathrm{O}(8)]$ to connect three different $\mathrm{Pb}(\mathrm{II})$ ions from the other asymmetric units, which extended to a $2 \mathrm{D}$ layer structure paralleled to the crystallographic $a b$ plane as shown in the left of Figure $3 b$. There is a $5.2 \AA$ pore consisted with two 1,3-pdta ligands and six $\mathrm{Pb}$ (II) atoms. The six-membered lead ring around the pore is shown in Figure $3 \mathrm{c}$. The void space accounts approximately $25.6 \%$ of the whole crystal volume calculated by PLATON [32] analysis. The adjacent 2D ring-like layers are further connected by the coordination bond $\mathrm{Pb}(1)-\mathrm{O}(8 \mathrm{a})$ (along the $b$ axis) as shown in Figure 3b-right. Finally, a complicated 3D MOF constructed from $\mathrm{Pb}(\mathrm{II})$ ions and 1,3-pdta ligands is formed.

The two distinct coordination environments of $\mathrm{Pb}(\mathrm{II})$ ions in this complex result in different 
connection modes for the metal ions in its topological description. If $\mathrm{Pb}(1), \mathrm{Pb}(2)$ ions and 1,3-pdta ligands were considered as three kinds of nodes, the 3D framework of $\mathbf{3}$ could be simplified into a $(3,3,6)$-connected trinodal $\mathrm{MnO}_{2}-\gamma$-type topological motif with a Schlafli symbol of $\left(4 \cdot 6^{2}\right)\left(4^{3}\right)\left(4^{4} \cdot 6^{8} \cdot 8^{3}\right)$ as shown in Figure S3a.

[Figures 3a, 3b and 3c]

The striking feature of the structure in $\mathbf{3}$ is the formation of $2 \mathrm{D}$ water layers. Six coordinated and crystallized water molecules connect to each other by hydrogen bonds. Water molecules and their symmetric equivalent atoms are joined together, forming a 2D water layer, as shown in Figure 3d. The 2D water layer is composed of a unique $\left(\mathrm{H}_{2} \mathrm{O}\right)_{26}$ cluster with central symmetry, which can be regarded as an evolution of a water chain by adding water molecules between the chains. Each O1wa acts as donor and acceptor to connect two O3w and bridges the water chains into a 2D layer. Within the water layer, two water molecules (O4w and O4wa) act as two hydrogen-bond donors with O8w and O8wa. On the other hand, O8w (O8wa) donors the hydrogen-bond to the $\mathrm{O} 4 \mathrm{w}(\mathrm{O} 4 \mathrm{wa})$ in return, forming a cyclic water tetramer [33]. The average $\mathrm{O} \cdots \mathrm{O}$ distance of the $\left(\mathrm{H}_{2} \mathrm{O}\right)_{26}$ cluster is $2.816 \AA$. This is longer than the corresponding value in ice $I_{\mathrm{h}}(2.759 \AA)$ [34] and shorter than that in liquid water $(2.854 \AA)$ [35], but within the values in the ice II phase $(2.77 \sim 2.84 \AA)$ [36]. Water clusters may play an important role in the stabilization of supramolecular systems both in solution and solid state [37]. The formation of the 2D water layer in $\mathbf{3}$ indicates that the intramolecular hydrogen bonds and the hydrogen-bond involving the carboxyl oxygen atoms play a crucial role in stabilizing the water layer and the host structure. Figure S3b displays the view paralleled to the ac plane of the packing structure, where the water layers are filled in the open channel of the host structure, and connected by hydrogen bonds $[\mathrm{O} 2 \mathrm{w}-\mathrm{H} 2 \mathrm{wa} \cdots \mathrm{O} 8$, $\mathrm{O} 8 \cdots \mathrm{H} 7 \mathrm{wa}-\mathrm{O} 7 \mathrm{w}, \mathrm{O} 6 \mathrm{w}-\mathrm{H} 6 \mathrm{wb} \cdots \mathrm{O} 1$ and $\left.\mathrm{O} 3 \mathrm{w}-\mathrm{H} 3 \mathrm{wb}^{\cdots} \cdot \mathrm{O} 2\right]$ to provide a stable structure. 


\subsubsection{Structure of $\left[\mathrm{Pb}_{2}(1,3-\mathrm{pdta})\left(\mathrm{H}_{2} \mathrm{O}\right)_{2}\right]_{\mathrm{n}}(4)$.}

$\left[\mathrm{Pb}_{2}(1,3 \text {-pdta })\left(\mathrm{H}_{2} \mathrm{O}\right)_{2}\right]_{\mathrm{n}}$ (4) comprises a three-dimensional polymeric network. The crystal structure of $\mathbf{4}$ contains one $\mathrm{Pb}$ atom, one coordinated water molecule and aminodicarboxyl groups of 1,3-pdta ligand in the asymmetric unit. $\mathrm{Pb}$ (II) ion exists in octadentate coordination environment, which contains six carboxyl oxygen atoms from four different 1,3-pdtas and two water molecules as shown in Figure 4. In the view paralleled to the crystallographic ab plane as shown in Figure S4a, 1,3-pdta acts as bis-tridentate $[\mathrm{O}(1)$, $\mathrm{O}(3), \mathrm{N}(1)]$ to chelate two $\mathrm{Pb}$ (II) ion and uses two carboxyl oxygen atoms $[\mathrm{O}(3), \mathrm{O}(4)]$ to bridge the other two adjacent asymmetric unit by coordinating with $\mathrm{Pb}$ (II) ions which extend to a $2 \mathrm{D}$ infinite network. The adjacent $2 \mathrm{D}$ layers are further connected by the coordination bond $\mathrm{Pb}(1)-\mathrm{O}(1 \mathrm{~b})$ and $\mathrm{Pb}(1)-\mathrm{O}(1 \mathrm{we})$ as shown in Figure S4b. Finally, a complicated 3D MOF constructed from $\mathrm{Pb}(\mathrm{II})$ ions and 1,3-pdta ligands is formed.

Topologically, each 1,3-pdta ligand was linked to eight $\mathrm{Pb}$ atoms to represent an 8-connected node, and each $\mathrm{Pb}$ atoms served for a 4-connected node through linking four 1,3-pdta ligands as shown in Figure S4c. The equivalent 3D topology framework for $\mathbf{4}$ could be viewed as a mixed binodal $(4,8)$-connected $s c u$-type topological motif with a Schlafli symbol of $\left(4^{16} \cdot 6^{12}\right)\left(4^{4} \cdot 6^{2}\right)_{2}$.

[Figure 4]

Table 1 shows the comparisons of bond distances in lead ethylenediaminetetraacetates and propylenediaminetetraacetates. It seems that lead-edta is much more compact than those of lead-pdta based on the comparisons of bond distances. This is attributed to the flexible propylenediamine chain in the ligand.

[Table 1] 


\subsection{NMR Analyses}

Solution ${ }^{13} \mathrm{C}$ NMR spectrum of $\mathbf{1}$ and solid state ${ }^{13} \mathrm{C}$ NMR spectra of $\mathbf{1} \sim \mathbf{4}$ are given in Figures 5 and 6, which supplied more information about the chemical environments of $-\mathrm{CO}_{2}$, $-\mathrm{CH}_{2} \mathrm{CO}_{2}$ and $-\mathrm{CH}_{2} \mathrm{~N}$ groups. The chemical shifts values are listed in Table 2. The chemical shifts for $-\mathrm{CO}_{2}$ in $\mathbf{1}$ show downfield signals at $181.78 \mathrm{ppm}$ and $178.12 \mathrm{ppm}$ for the solution and solid state respectively. This indicates that the four carboxyl groups were in similar chemical environment with strong hexadentate chelation. It gives much downfield signal in solution which is attributed to the strong coordination of water molecules. The slightly high field shift in solid may be the evidence the coordination polymer $\mathbf{1}$ dissociates into monomeric species after dissolution as following:

$$
\left[\mathrm{Pb}_{2}(1,3-\text { pdta })_{2}\right]_{\mathrm{n}}{ }^{4-}+4 \mathrm{H}_{2} \mathrm{O} \leftrightarrows 2\left[\mathrm{~Pb}(1,3-\text { pdta })\left(\mathrm{H}_{2} \mathrm{O}\right)_{2}\right]^{2-}
$$

This is also supported by the double signals for $-\mathrm{CH}_{2} \mathrm{~N}$ and $-\mathrm{NCH}_{2} \mathrm{CO}_{2}$ in solid state respectively, while only one signal exists in solution.

[Figures 5 and 6] [Table 2]

Chemical shifts for $-\mathrm{CO}_{2}$ in 2 show three highfiled signals at 173.40, 170.80 and 169.87 ppm in consistent with the formation of tertiary ammonium salt. The peaks can be ascribed to the three types of coordination modes of the carboxyl groups as shown in Figure $2\left(\mathrm{C}_{2}, \mathrm{C}_{4}\right.$ and $\mathrm{C}_{8}$ ). The chemical shifts for $-\mathrm{CO}_{2}$ in $\mathbf{3}$ show four downfield signals at $185.29,183.41,181.56$ and $178.84 \mathrm{ppm}$. The peaks can be ascribed to the four types of coordination modes of carboxyl groups as shown in Figure $3 \mathrm{a}\left(\mathrm{C}_{1}, \mathrm{C}_{3}, \mathrm{C}_{9}, \mathrm{C}_{11}\right)$. The chemical shifts for $-\mathrm{CO}_{2}$ in 4 give two downfield signals at 181.19 and $178.65 \mathrm{ppm}$. The two peaks can be ascribed to the two types of coordination modes for the carboxyl groups as shown in Figure $4\left(\mathrm{C}_{2}, \mathrm{C}_{4}\right)$.

\subsection{Thermal properties and IR spectra}


The TG-DTG curves and analysis of $\mathbf{1} \sim \mathbf{4}$ are showed in Figure S5 and Table S2. It seems 3 is stable up to $200{ }^{\circ} \mathrm{C}$. The IR spectra for $\mathbf{1} \sim \mathbf{4}$ are presented in Figure S6.

\subsection{Adsorption of methanol with $\left\{\left[\mathrm{Pb}_{2}(1,3-\text { pdta })\left(\mathrm{H}_{2} \mathrm{O}\right)_{4}\right] \cdot 4 \mathrm{H}_{2} \mathrm{O}\right\}_{n}(3)$.}

The unique $5.2 \AA$ pore and the high porosity for $\mathbf{3}$ may display the ability to selectively adsorb sizable macromolecules, so the adsorption and desorption experiments on $\mathbf{3}$ were conducted. There is no macroscopic change when $\mathbf{3}$ were immersed in ethanol for one week. The structural analysis shows the same structure without ethanol in the pores. The results demonstrate that the pores of $\mathbf{3}$ are not suitable for ethanol adsorption.

In contrast to the ethanol, methanol could be adsorbed easily at room temperature in a short time, where sample 3a was obtained. The strong interaction between methanol and $\mathbf{3}$ shows that methanol inserts to the channel in $\mathbf{3}$. The desorbed sample $\mathbf{3 b}$ was obtained by heating $\mathbf{3 a}$ at $60{ }^{\circ} \mathrm{C}$ for 1 hour. The relative amount of methanol absorbed for $\mathbf{3}$ obtained from gas chromatographic analysis is $8.37 \mathrm{mg} / \mathrm{mmol}$, which is in close to the calculated amount $(9.25$ $\mathrm{mg} / \mathrm{mmol}$ ) that each pore adsorbed one methanol molecule. The reabsorbed sample 3c was obtained by immersing $\mathbf{3 b}$ in water for 6 hours. These will be discussed later in ${ }^{13} \mathrm{C}$ solid NMR and PXRD sections.

As we can see in the Figure 7 , the XRD patterns demonstrate a well microporous framework remains after the adsorption and release with methanol and reabsorption with water, when compared with the powder X-ray diffraction spectra of $\mathbf{3}, \mathbf{3 a}, \mathbf{3 b}$ and $\mathbf{3 c}$.

\section{[Figure 7]}

Figure 8 shows the ${ }^{13} \mathrm{C}$ solid NMR spectra of solid $\mathbf{3}, \mathbf{3 a}$ and $\mathbf{3 c}$. The data of chemical shifts are listed in Table 3. The four chemical shift signals for $-\mathrm{CO}_{2}$ for $3(178.84,181.56$, $183.41,185.29 \mathrm{ppm})$ were decreased to two peak in 3a $(177.77,179.05 \mathrm{ppm})$. The chemical shift of $-\mathrm{CO}_{2}$ shows an obvious highfield shift, supporting the interaction between the 
methanol and the carboxyl groups of 1,3-pdta. Moreover, a new peak at $59.22 \mathrm{ppm}$ can be ascribed to methyl groups of methanol in the open-channel. The methyl group of methanol shows a strong downfield shift $(\Delta \delta=9.72 \mathrm{ppm})$ compared with methanol in $\mathrm{D}_{2} \mathrm{O}$. The downfield shift can be attributed to the nano-effects of the hydrophobic interaction between methyl group in methanol and methylene groups in 1,3-pdta, indicating the existence of nano-confined methanol in the open channel of 3 . The speculative illustration is shown in Figure S7 for methanol in the open channel, showing the interaction between methyl group in methanol and methylene groups is hydrophobic. There are two interactions driving for methanol molecules into the channels. One is the van der Waals force between methyl group in methanol and methylene groups in channels. The other is the interaction between hydroxy group of methanol and carboxyl groups in channels. The phenomenon is similar to that in lanthanum propylenediaminetetraacetate $\left\{\mathrm{La}\left(\mathrm{H}_{2} \mathrm{O}\right)_{4}\left[\mathrm{La}(1,3-\text { pdta })\left(\mathrm{H}_{2} \mathrm{O}\right)\right]_{3}\right\}_{n} \cdot 12 \mathrm{nH}_{2} \mathrm{O}$ reported for ethanol adsorption [18].

[Figure 8] [Table 3]

Solid state ${ }^{13} \mathrm{C}$ NMR spectra of $\mathbf{3}$ showed that the sample can return to its original microporous structure after methanol desorption with water, which give supports to the reversible adsorption for $\left\{\left[\mathrm{Pb}_{2}(1,3-\mathrm{pdta})\left(\mathrm{H}_{2} \mathrm{O}\right)_{4}\right] \cdot 4 \mathrm{H}_{2} \mathrm{O}\right\}_{\mathrm{n}}$ (3). The TG/DTG curve in 3a (Figure S8) demonstrates that the releasing temperature for the methanol is approximate to 55 ${ }^{\circ} \mathrm{C}$, showing strong interaction of methanol in microporous structure.

\section{Conclusion}

In summary, four novel lead 1,3-pdta complexes have been isolated from the reactions of lead nitrate and 1,3-pdta ligand. The $\mathrm{pH}$ values, concentration and the molar ratios of reactants would influence the coordination modes of 1,3-pdta to form different products. 
Water soluble potassium lead 1,3-propylenediaminetetraacetate is converted to insoluble coordination polymers $\mathbf{3}$ and $\mathbf{4}$. Interestingly, $\mathbf{3}$ are stable with microporous structure and can be used for the selective and reversible adsorption of methanol. Efforts to 1,3-pdta chelated MOFs with intriguing microporous are ongoing. 


\section{Acknowledgements}

We thank the National Science Foundation of Fujian, Research Funds for the Central Universities (No.20720150041) and the Program for Innovative Research Team in Chinese Universities (No. IRT_14R31) for their generous financial supports. 


\section{References}

[1] A.M.A. Haidar, K.M. Muttaqi, D. Sutanto, Energy Conv. Manage. 86 (2014) 689.

[2] D. Linden, T.B. Reddy, eds. Handbook of Batteries, New York: McGraw-Hill, 3rd ed., 2002, pp. 23.

[3] D.V. Thompson, The Materials and Techniques of Medieval Painting, Dover Publications Inc., 1956, pp. 90.

[4] R. Nevin, Environ. Res. 83 (2000) 1.

[5] R. Nevin, Environ. Res. 104 (2007) 315.

[6] D.R. Laurence, Clinical Pharmacology, J \& A Churchill Ltd, 3rd ed., 1966.

[7] D.D. Radanovic, U. Rychlewska, M.I. Djuran, B. Warzajtis, N.S. Draskovic, D.M.

Guresic, Polyhedron 23 (2004) 2183.

[8] D.D. Radanovic, U. Rychlewska, M.I. Djuran, N.S. Draskovic, M.M. Vasojevic, I.M.

Hodzic, D.J. Radanovic, Polyhedron 22 (2003) 2745.

[9] N.S. Draskovic, M.I. Djuran, M.S. Cvijovic, D.D. Radanovic, V. Jevtovic, Transition Met. Chem. 29 (2004) 874.

[10] S. Beloševic', M.M. Vasojevic', M.S. Jeremic', A. Meetsma, Z.D. Matovic', J. Coord. Chem. 66 (2013) 1730.

[11] D.J. Radanovic, T. Ama, H. Kawaguchi, N.S. Draskovic, D.M. Ristanovic, S. Janicijevic, Bull. Chem. Soc. Jpn. 74 (2001) 701.

[12] U. Rychlewska, D.D. Radanovic, V.S. Jevtovic, D.J. Radanovic, Polyhedron 19 (2000) 1.

[13] M. Hernandez-Padilla, E. Chinea, S. Dominguez, A. Mederos, M.C. Munoz, F. Lloret, Polyhedron 19 (2000) 1175.

[14] U. Rychlewska, D.M. Guresic, B. Warzajtis, D.D. Radanovic, M.I. Djuran, Polyhedron 24 (2005) 2009. 
[15] U. Rychlewska, B. Warzajtis, D. Cvetic, D.D. Radanovic, D.M. Guresic, M.I. Djuran, Polyhedron 26 (2007) 1717.

[16] M.L. Chen, Y.H. Hou, W.S. Xia, Z.H. Zhou, J. Coord. Chem. 66 (2013) 1906.

[17] M.L. Chen, F. Yang, Z.H. Zhou, Polyhedron 47 (2012) 60.

[18] M.L. Chen, Y.C. Guo, F. Yang, J.X. Liang, Z.X. Cao, Z.H. Zhou, Dalton Trans. 43 (2014) 6026.

[19] U. Rychlewska, B. War. Zajtis, D.D. Radanović , N.S. Draš ković , I.M. Stanojevic ,

M.I. Djuran, Polyhedron 30 (2011) 983.

[20] Y.B. He, W. Zhou, G.D. Qian, B.L. Chen, Chem. Soc. Rev. 43 (2014) 5657.

[21] Y. Hijikata, S. Horike, M. Sugimoto, M. Inukai, T. Fukushima, S. Kitagawa, Inorg. Chem. 52 (2013) 3634.

[22] W.L. Lou, J.F. Yang, L.B. Li, J.P. Li, J. Solid State Chem. 213 (2014) 224.

[23] J. Lee, J. Li, J. Jagiello, J. Solid State Chem. 178 (2005) 2527.

[24] W.W. Xu, S. Pramanik, Z.J. Zhang, T.J. Emge, J. Li, J. Solid State Chem. 200 (2013) 1.

[25] Q. Huang, J.F. Cai, H. Wu, Y.B. He, B.L. Chen, G.D. Qian, J. Mater. Chem. 22 (2012) 10352.

[26] Z. Zhao, X. He, Y.M. Zhao, M. Shao, S.R. Zhu, Dalton Trans. 15 (2009) 2802.

[27] K. Uemura, F. Onishi, Y. Yamasaki, H. Kita, J. Solid State Chem. 182 (2009) 2852.

[28] G.M. Sheldrick, SHELXS-97,SHELXL-97, and SHELXTL/PC, Programs for solution and refinement of crystal structures, University of Göttingen, Göttingen, 1997.

[29] O.V. Dolomanov, L.J. Bourhis, R.J. Gildea, J.A.K. Howard, H. Puschmann, J. Appl. Cryst. 42 (2009) 339.

[30] L.J. Farrugia, J. Appl. Cryst. 45 (2012) 849.

[31] J. Wang, Z.R. Liu, X.D. Zhang, W.G. Jia, D.M. Fan, Chinese J. Struct. Chem. 22 (2003) 454. 
[32] A.L. Spek, PLATON, A Multipurpose Crystallographic Tool, Utrecht University, Utrecht, The Netherlands, 2008.

[33] S.Q. Bai, T.S. Andy Hor, Chem. Commun. 27 (2008) 3172.

[34] D. Eisenberg, W. Kauzmann, The Structure and Properties of Water, Oxford University Press, Oxford, UK, 1969.

[35] A.C. Belch, S.A. Rice, J. Chem. Phys. 86 (1987) 5676.

[36] G.A. Jeffrey, An Introduction to Hydrogen Bondings, Oxford University Press, Oxford, UK, 1997, pp. 160- 180.

[37] L.Y. Wang, Y. Yang, K. Liu, B.L. Li, Y. Zhang, Cryst. Growth. Des. 8 (2008) 3902.

[38] Q.B. Bo, J.J. Pang, H.Y. Wang, C.H. Fan, Z.W. Zhang, Inorg. Chim. Acta 428 (2015) 170.

[39] A.L. Poznyak, G.N. Kupriyanova, I.F. Burshtein, A.B. Ilyukhin, Russ. J. Coord. Chem. $24(1998) 825$.

[40] A.B. Ilyukhin, V.B. Logvinova, R.L. Davidovich, Russ. J. Inorg. Chem. 44 (1999) 1654. 


\section{Figure captions}

Scheme 1. Conversions of water soluble coordination polymer $\left\{\mathrm{K}_{4}\left[\mathrm{~Pb}_{2}(1,3-\mathrm{pdta})_{2}\right] \cdot 6 \mathrm{H}_{2} \mathrm{O}\right\}_{\mathrm{n}}(\mathbf{1})$ to $\left\{\left[\mathrm{Pb}_{2}(1,3-\text { pdta })\left(\mathrm{H}_{2} \mathrm{O}\right)_{4}\right] \cdot 4 \mathrm{H}_{2} \mathrm{O}\right\}_{\mathrm{n}}(3)$ and $\left[\mathrm{Pb}_{2}(1,3-\text { pdta })\left(\mathrm{H}_{2} \mathrm{O}\right)_{2}\right]_{\mathrm{n}}(4)$.

Figure 1. Dimeric unit in $\mathrm{K}_{4 n}\left[\mathrm{~Pb}_{2}(1,3-\mathrm{pdta})_{2}\right]_{\mathrm{n}} \cdot 6 \mathrm{nH}_{2} \mathrm{O}$ (1).Symmetry codes: $a(2-x, 1-y, 1-$ $z)$.

Figure 2. Structural diagram of $\left\{\left[\mathrm{Pb}\left(1,3-\mathrm{H}_{2} \text { pdta }\right)\left(\mathrm{H}_{2} \mathrm{O}\right)\right] \cdot 2 \mathrm{H}_{2} \mathrm{O}\right\}_{\mathrm{n}}(2)$. Symmetry codes: $a(x$, $1+y, z), b(-1 / 2+x,-1 / 2-y, 1 / 2+z), c\left(1 \frac{1 / 2}{2} x, 1 / 2+y, 1 \frac{1}{2}-\mathrm{z}\right)$.

Figure 3a. Structural diagram of $\left\{\left[\mathrm{Pb}_{2}(1,3-\mathrm{pdta})\left(\mathrm{H}_{2} \mathrm{O}\right)_{4}\right] \cdot 4 \mathrm{H}_{2} \mathrm{O}\right\}_{\mathrm{n}}(3)$. Symmetry codes: $a(1+$ $x,+y,+z), b(1+x, 1 / 2-y, 1 / 2+z), c(-1+x, y,-1+z), d(-1-x,-y,-1-z)$.

Figure 3b. The infinite 3D structures of $\left\{\left[\mathrm{Pb}_{2}(1,3-\text { pdta })\left(\mathrm{H}_{2} \mathrm{O}\right)_{4}\right] \cdot 4 \mathrm{H}_{2} \mathrm{O}\right\}_{\mathrm{n}}(3)$ (remove the guest water molecules) parallel to the ac plane(left) and bc plane(right).

Figure 3c. The six-membered lead ring around the $5.2 \AA$ pore of $\left\{\left[\mathrm{Pb}_{2}(1,3-\text { pdta })\left(\mathrm{H}_{2} \mathrm{O}\right)_{4}\right] \cdot 4 \mathrm{H}_{2} \mathrm{O}\right\}_{\mathrm{n}}(3)$ (remove the guest water molecules)

Figure 3d. 2D water layers in $\left\{\left[\mathrm{Pb}_{2}(1,3-\text { pdta })\left(\mathrm{H}_{2} \mathrm{O}\right)_{4}\right] \cdot 4 \mathrm{H}_{2} \mathrm{O}\right\}_{\mathrm{n}}(3)$ parallel to the $b c$ plane.

Figure 4. Structural diagram of $\left[\mathrm{Pb}_{2}(1,3-\mathrm{pdta})\left(\mathrm{H}_{2} \mathrm{O}\right)_{2}\right]_{\mathrm{n}}$ (4). Symmetry codes: $a(-x, y, 1 / 2-z), b$ $(x,-y, 1 / 2+z), c(1 / 2-x, 1 / 2-y,-z), d(1 / 2-x,-1 / 2+y, 1 / 2-z), e(-x,-y,-z), f(-1 / 2+x, 1 / 2-y, 1 / 2+z)$, $g(-1 / 2+x,-1 / 2+y, z), h(x,-y,-1 / 2+z), i(-x,-y, 1-\mathrm{z})$.

Figure 5. Solution ${ }^{13} \mathrm{C}$ NMR spectrum of $\left\{\mathrm{K}_{4}\left[\mathrm{~Pb}_{2}(1,3-\text { pdta })_{2}\right] \cdot 6 \mathrm{H}_{2} \mathrm{O}\right\}_{n}(\mathbf{1})$.

Figure 6. Solid state ${ }^{13} \mathrm{C}$ NMR spectra of $\left\{\mathrm{K}_{4}\left[\mathrm{~Pb}_{2}(1,3-\text { pdta })_{2}\right] \cdot 6 \mathrm{H}_{2} \mathrm{O}\right\}_{\mathrm{n}}(\mathbf{1})$, $\left\{\left[\mathrm{Pb}\left(1,3-\mathrm{H}_{2} \text { pdta }\right)\left(\mathrm{H}_{2} \mathrm{O}\right)\right] \cdot 2 \mathrm{H}_{2} \mathrm{O}\right\}_{\mathrm{n}}(\mathbf{2}),\left\{\left[\mathrm{Pb}_{2}(1,3-\text { pdta })\left(\mathrm{H}_{2} \mathrm{O}\right)_{4}\right] \cdot 4 \mathrm{H}_{2} \mathrm{O}\right\}_{\mathrm{n}}(\mathbf{3})$ and 
$\left[\mathrm{Pb}_{2}(1,3-\mathrm{pdta})\left(\mathrm{H}_{2} \mathrm{O}\right)_{2}\right]_{\mathrm{n}}(4)$.

Figure 7. The simulated and experimental XRD patterns for $\left\{\left[\mathrm{Pb}_{2}(1,3-\mathrm{pdta})\left(\mathrm{H}_{2} \mathrm{O}\right)_{4}\right] \cdot 4 \mathrm{H}_{2} \mathrm{O}\right\}_{\mathrm{n}}$ (3), 3a is the sample after methanol adsorption, $\mathbf{3 b}$ is the adsorbed sample after heating at 60 ${ }^{\circ} \mathrm{C}$, and $\mathbf{3 c}$ is the adsorbed sample after water treatment.

Figure 8. Solid ${ }^{13} \mathrm{C}$ NMR spectra of $\left\{\left[\mathrm{Pb}_{2}(1,3-\text { pdta })\left(\mathrm{H}_{2} \mathrm{O}\right)_{4}\right] \cdot 4 \mathrm{H}_{2} \mathrm{O}\right\}_{\mathrm{n}}(3)$ after adsorption with methanol (3a) and re-dissolution in water (3c).

Table 1. Comparisons of the selected bond distances $(\AA)$, coordination number (C.N.) of lead ion and dentate number (D.N.) of 1,3-pdta (or edta) for $\mathbf{1} \sim \mathbf{4},\left[\mathrm{Pb}_{4}(1,3-\text { pdta })(\text { aip })_{2}\left(\mathrm{H}_{2} \mathrm{O}\right)_{4}\right]_{\mathrm{n}}(\mathbf{5}$, $\mathrm{H}_{2}$ aip = 5-aminoisophthalic acid) [38], $\mathrm{K}_{2}\left[\mathrm{~Pb}(\right.$ edta) $] \cdot 4 \mathrm{H}_{2} \mathrm{O}(\mathbf{6})$ [31], $\left[\mathrm{Pb}_{2}(\text { edta })_{2}\left(\mathrm{H}_{2} \mathrm{O}\right)_{2}\right]_{\mathrm{n}} \cdot \mathrm{nH}_{2} \mathrm{O}$ (7) [39] and $\left(\mathrm{NH}_{4}\right)_{4 \mathrm{n}}\left[\mathrm{Pb}_{2}(\text { edta })_{2}\right]_{n} \cdot 5 \mathrm{nH}_{2} \mathrm{O}(\mathbf{8})[40]$.

Table 2. ${ }^{13} \mathrm{C}$ NMR spectral data (in ppm) of complexes $\mathbf{1} \sim \mathbf{4}$.

Table $3 .{ }^{13} \mathrm{C}$ NMR spectral data (in ppm) of $\mathbf{3}, \mathbf{3 a}, \mathbf{3 c}$. 


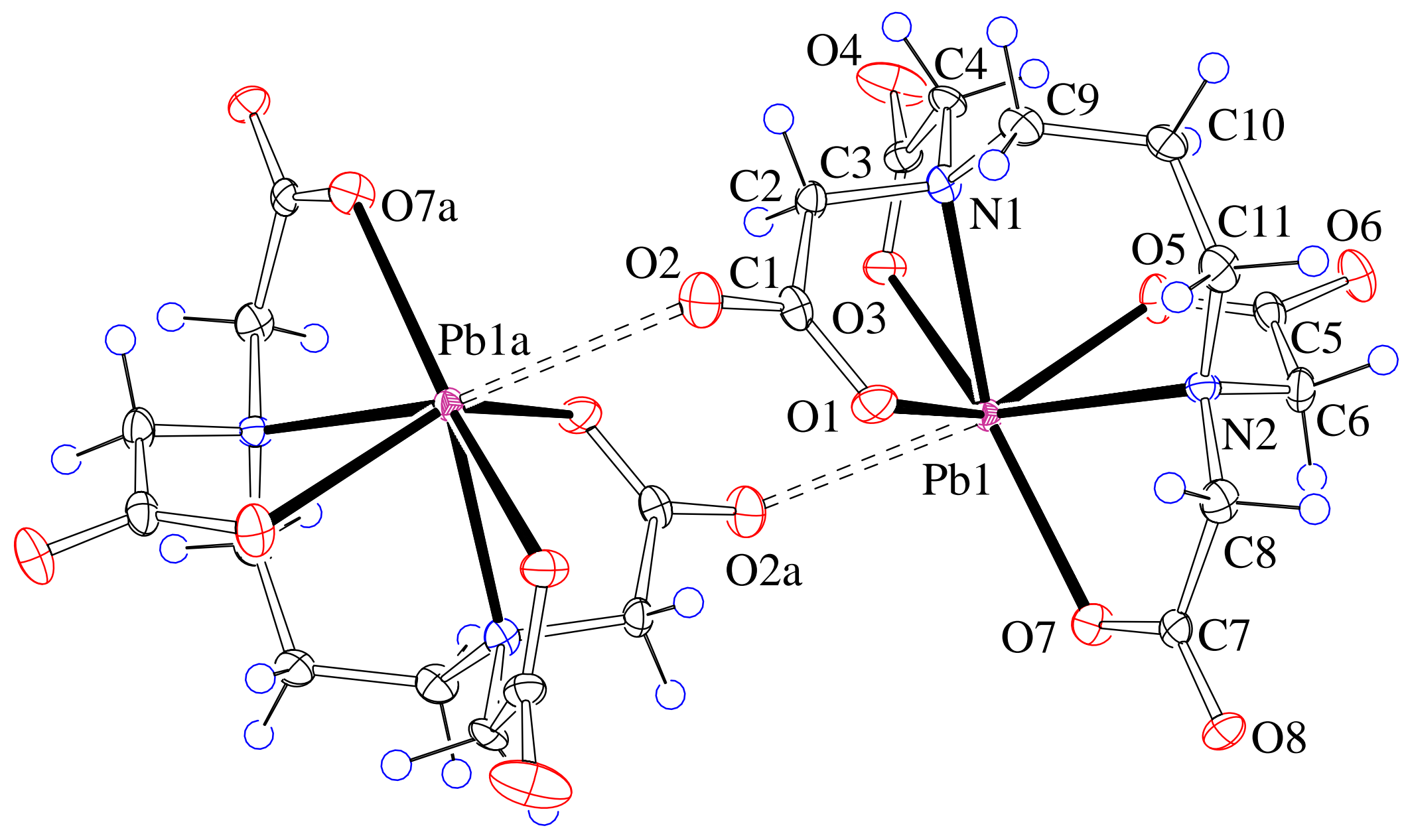




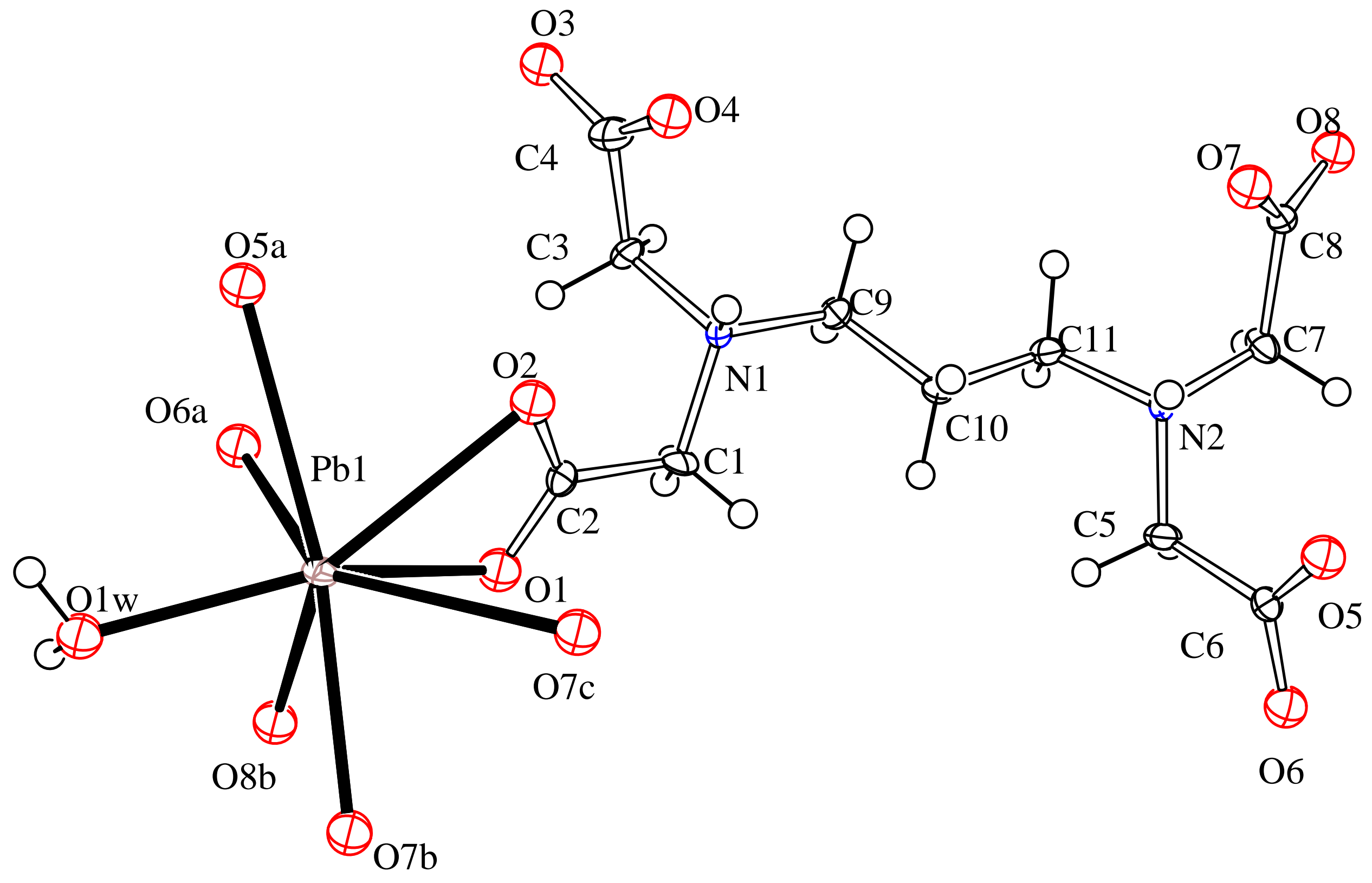




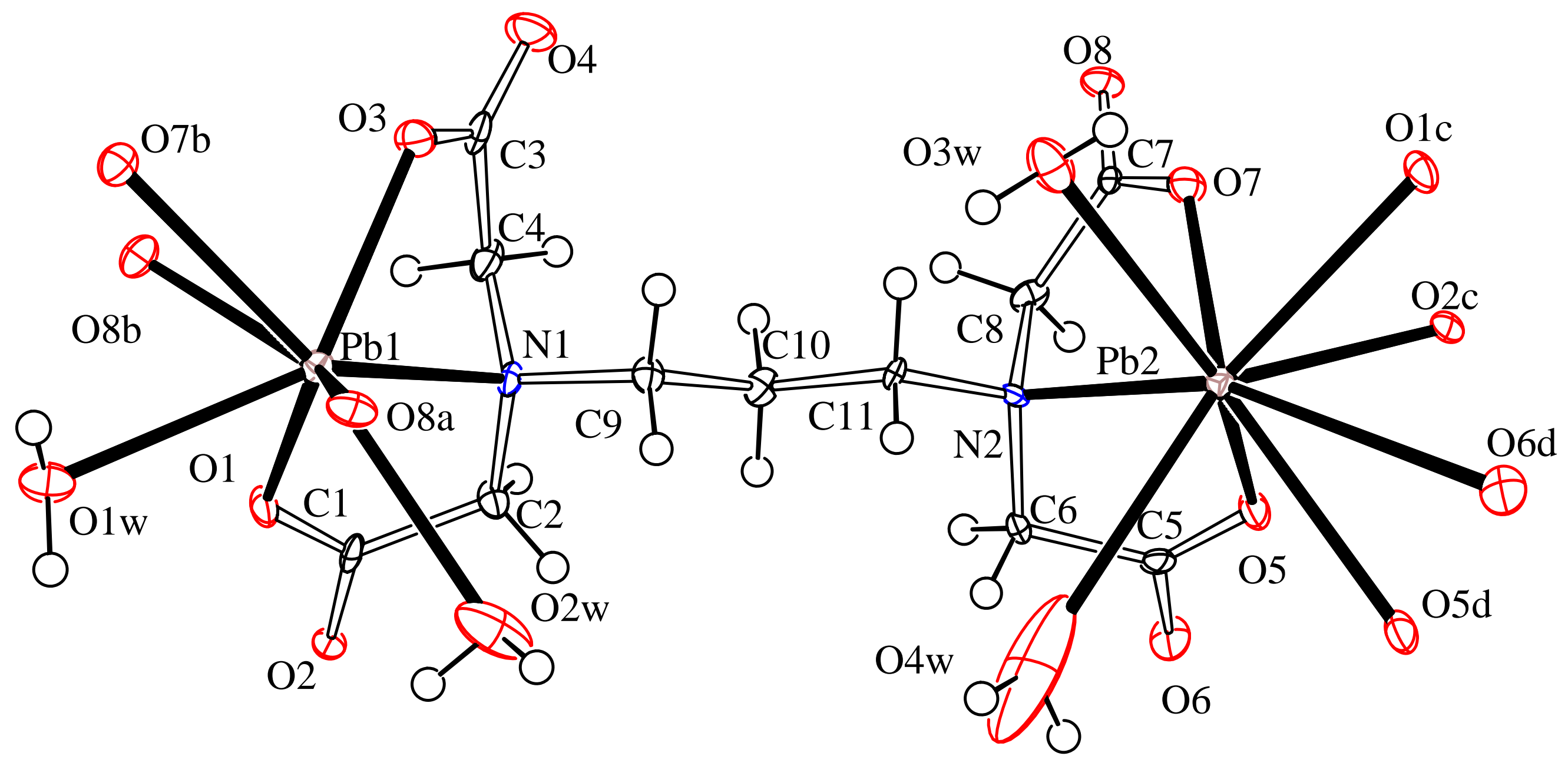




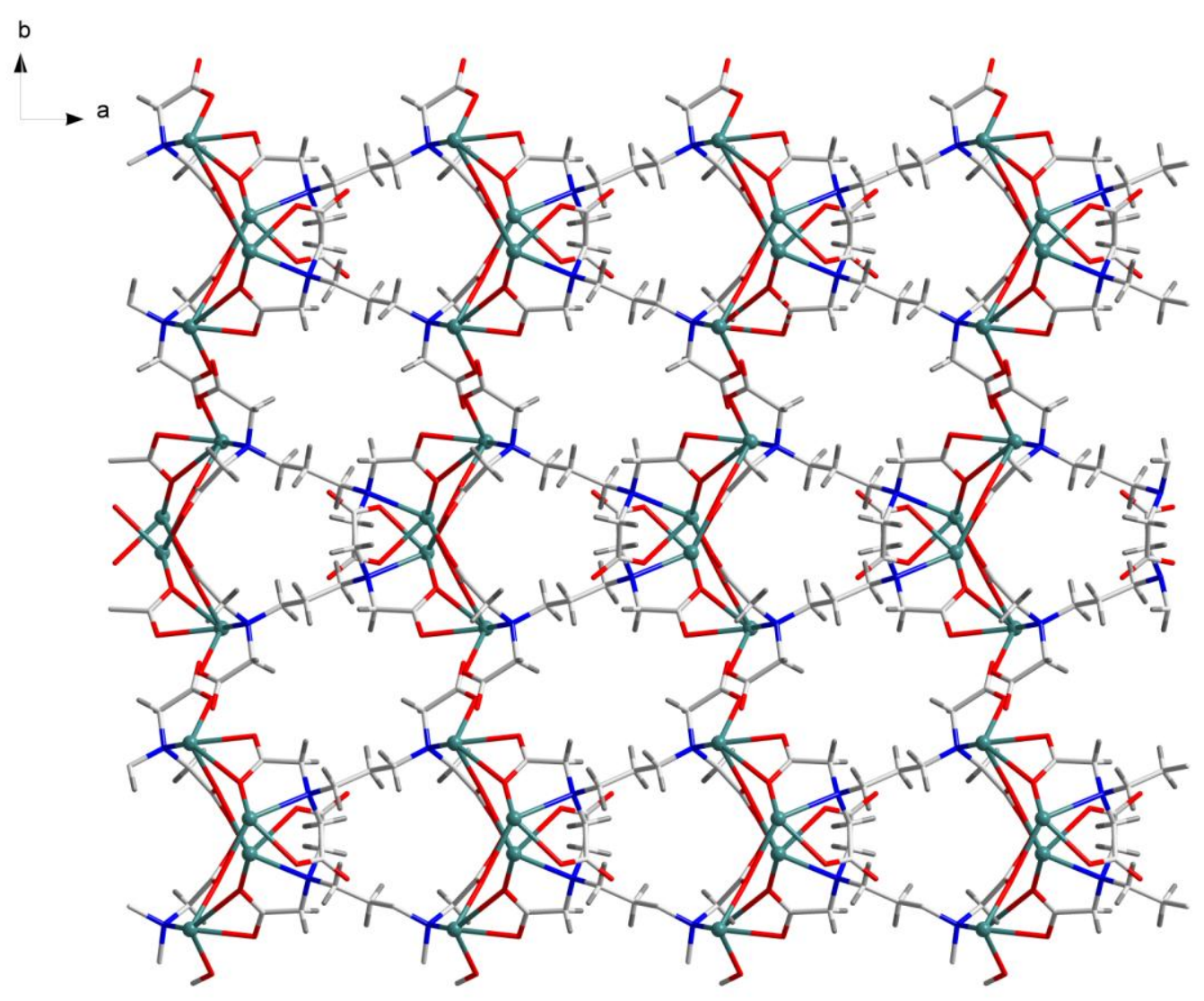




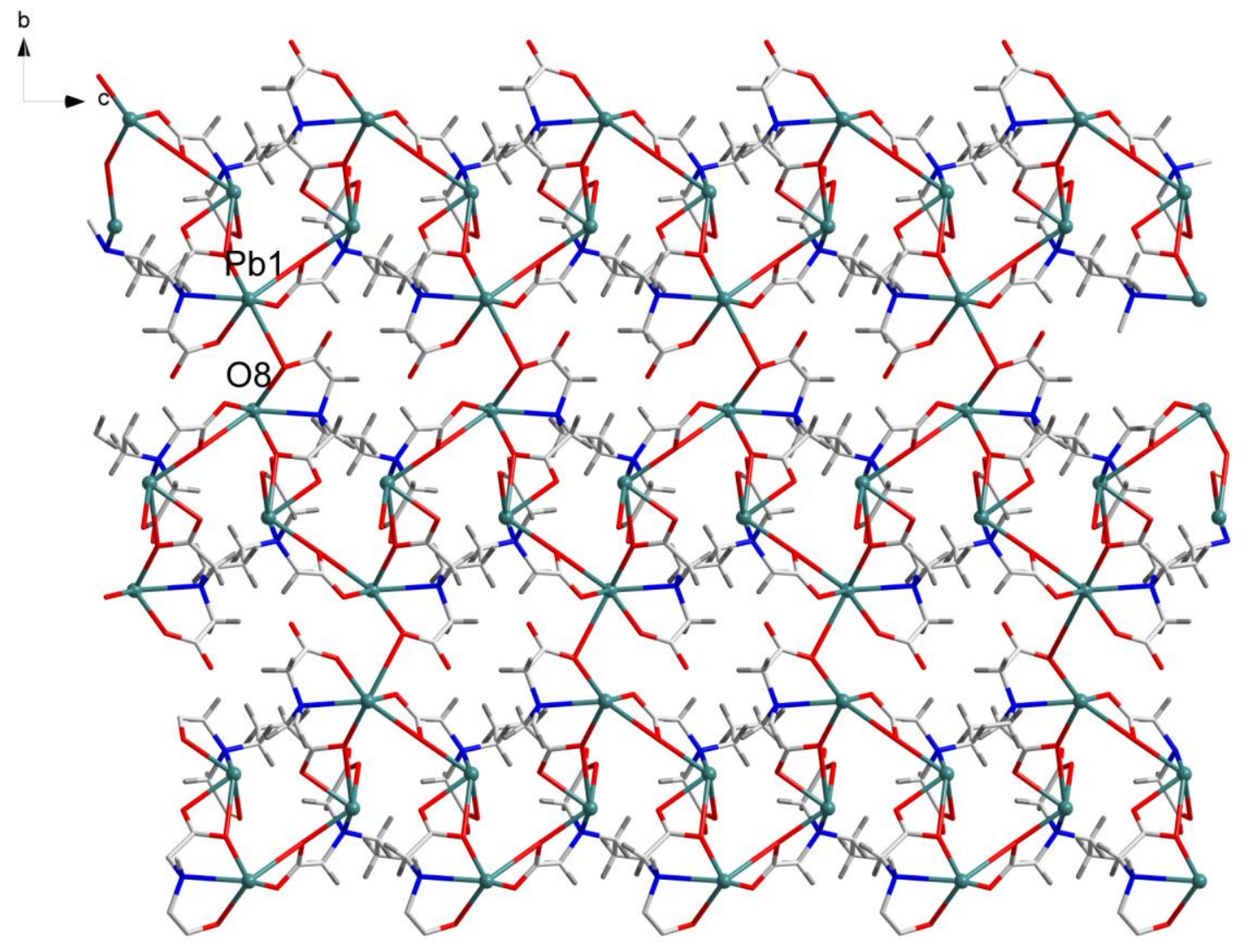




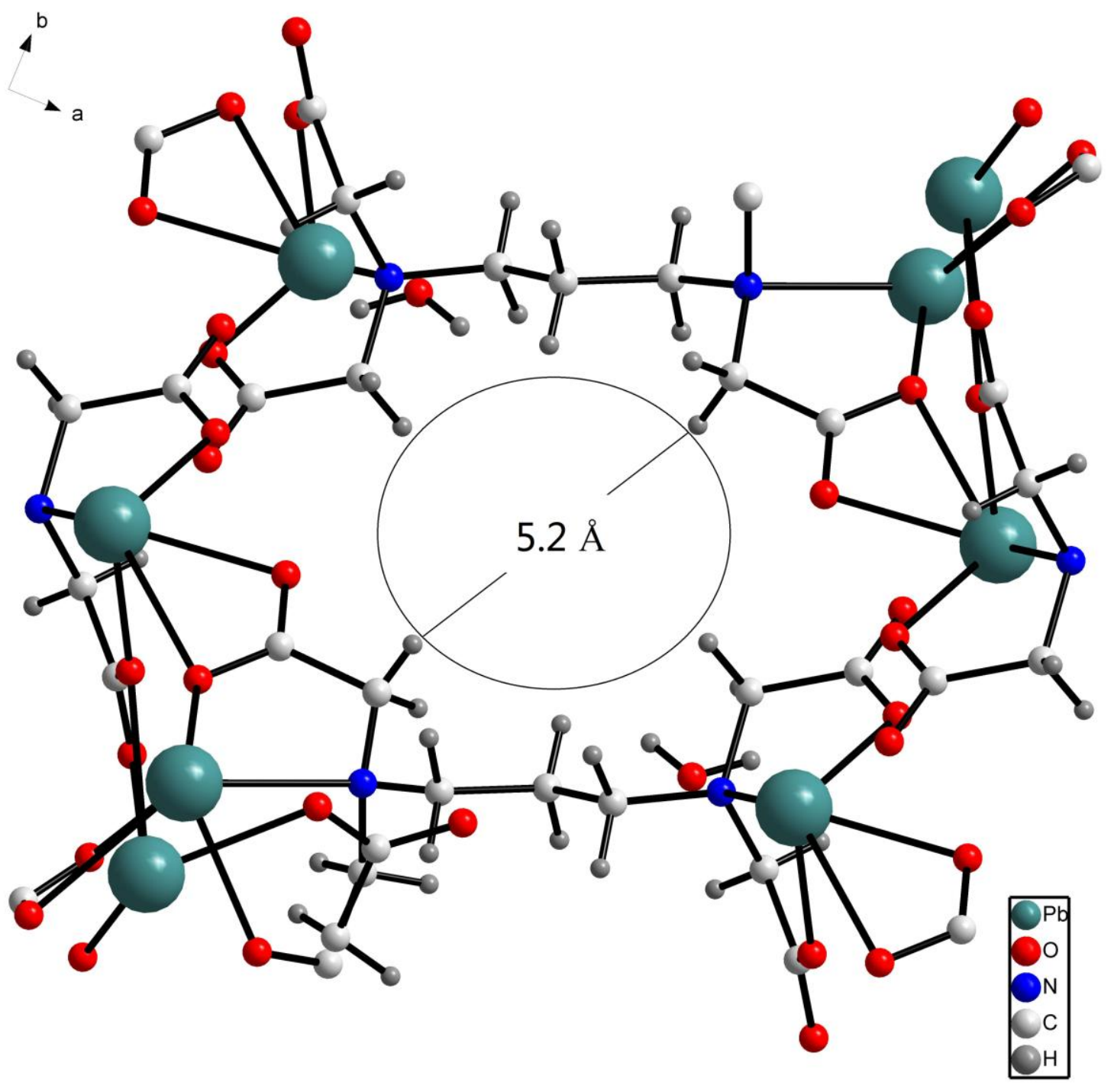




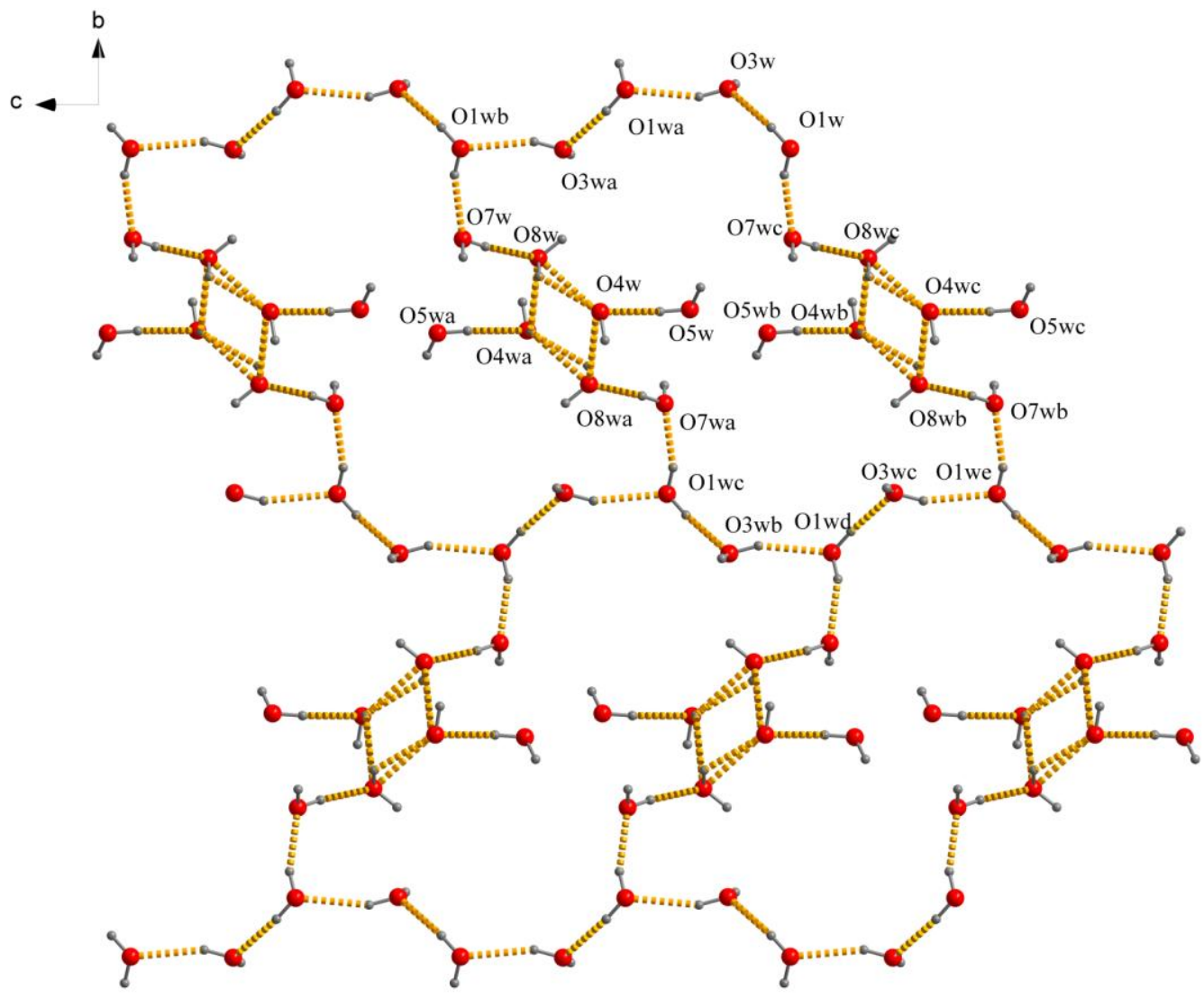




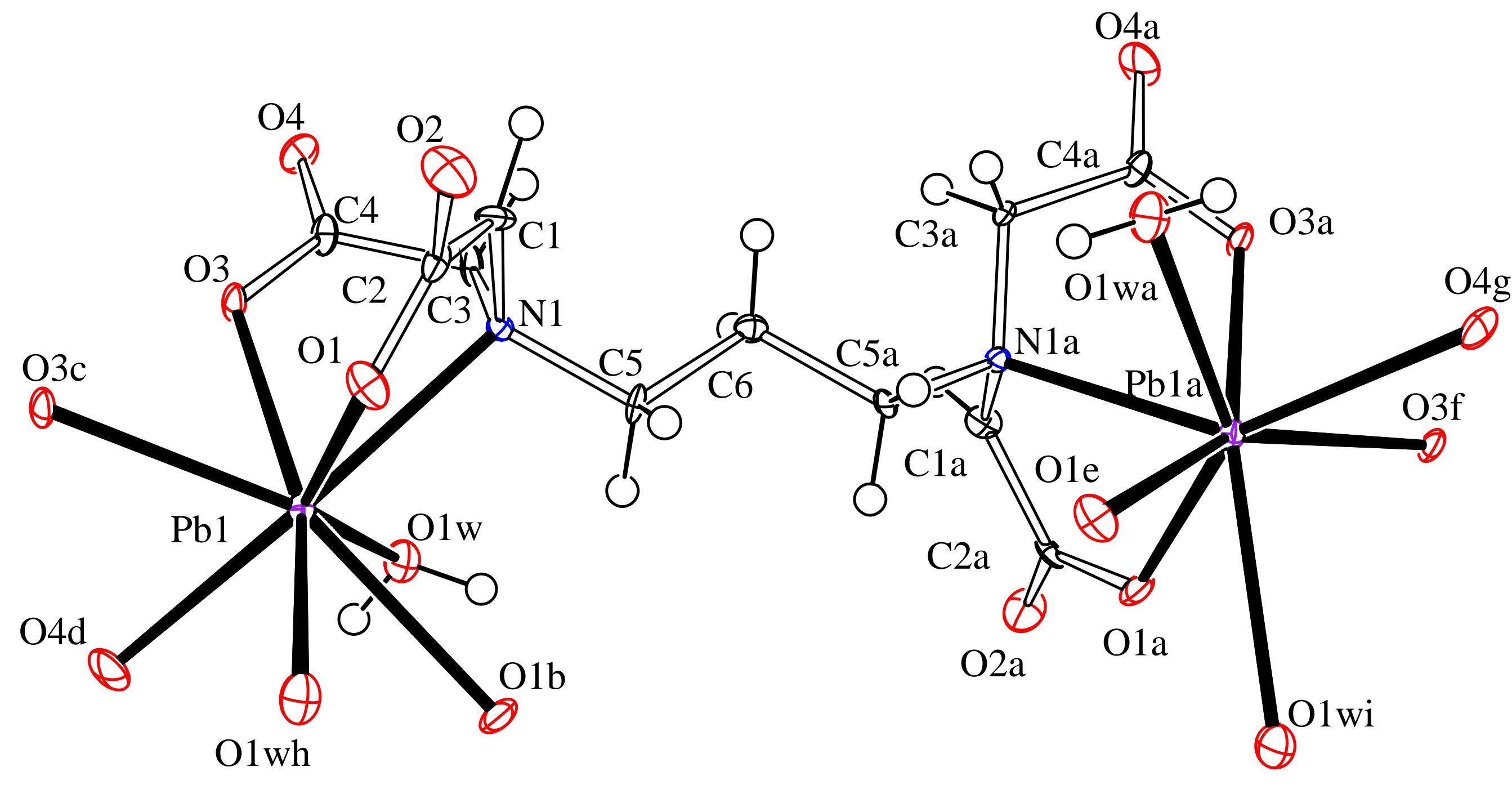




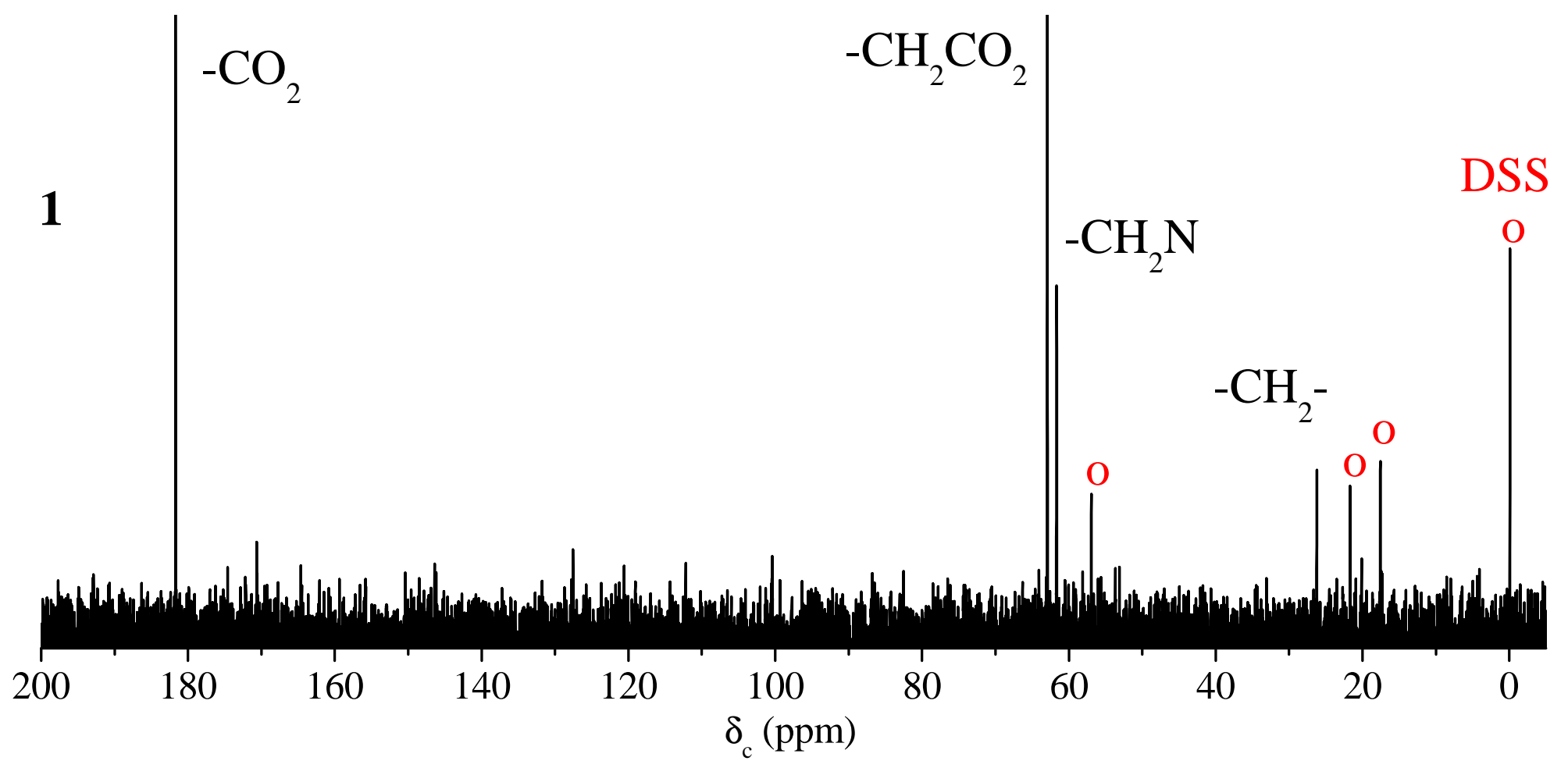




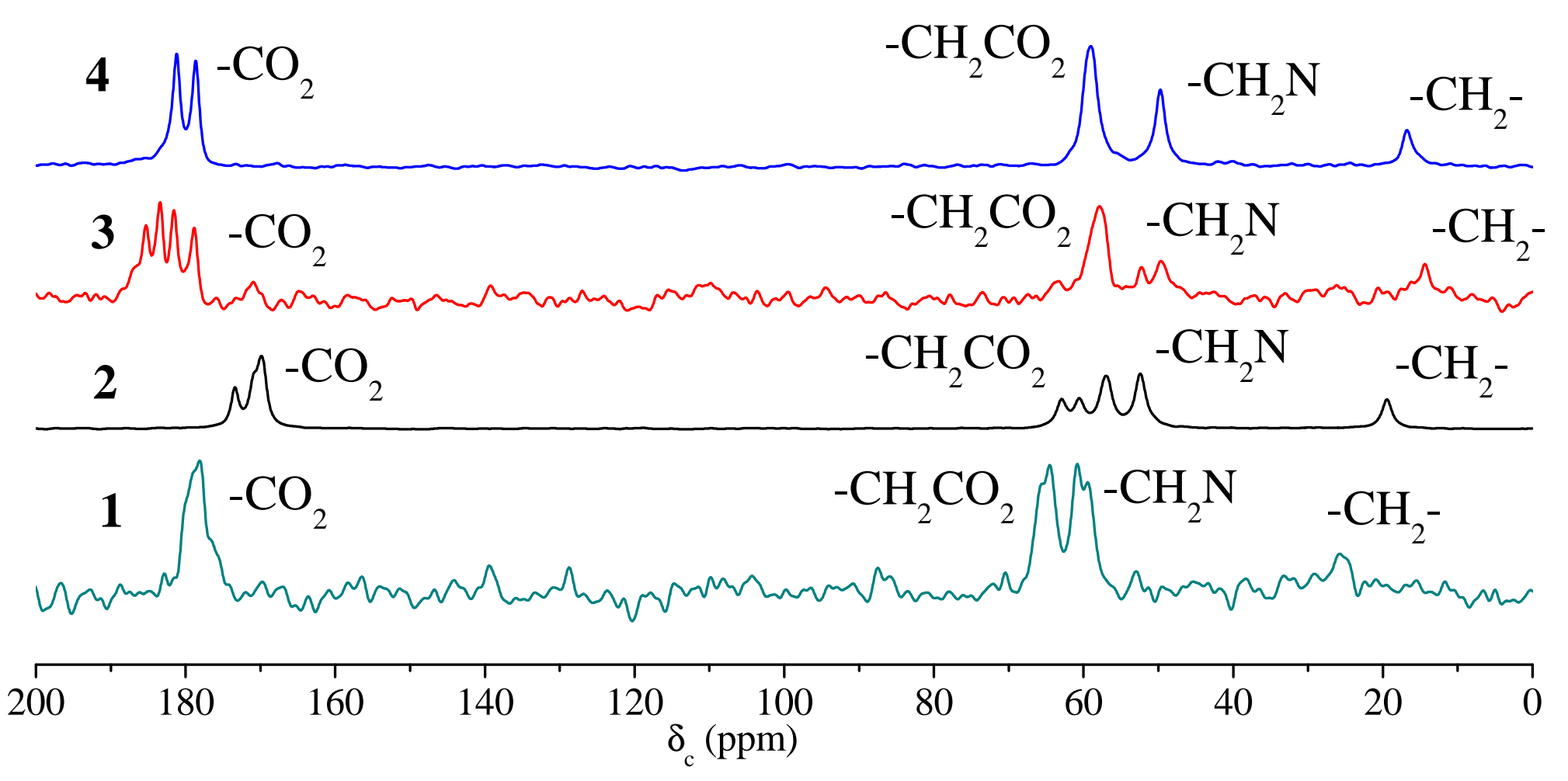




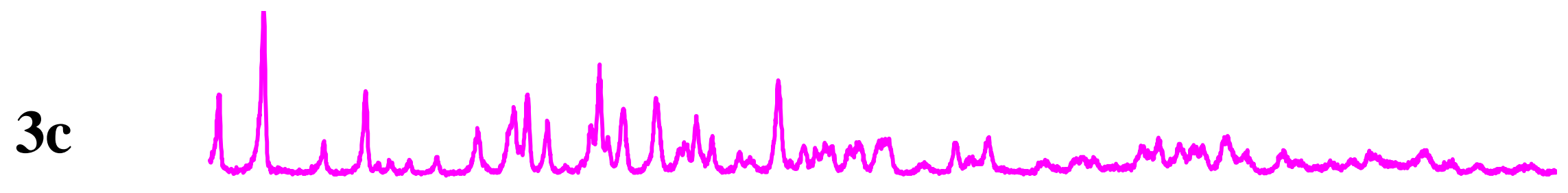

3b

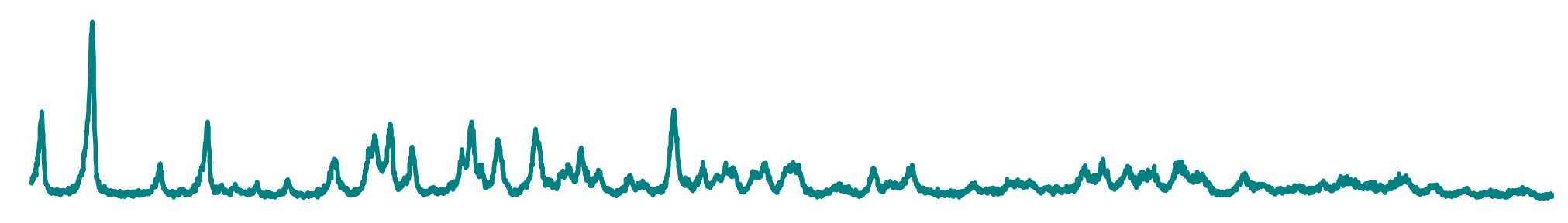

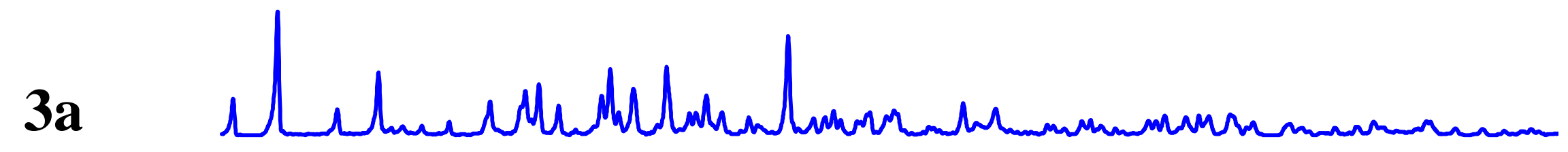

3

(experment)

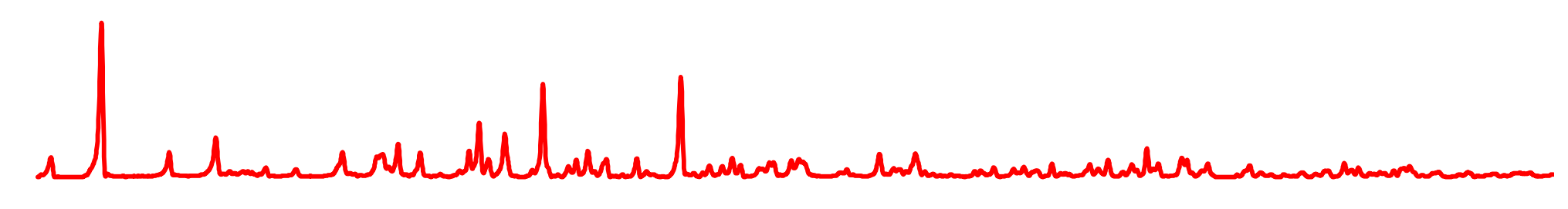

3

(simulated)
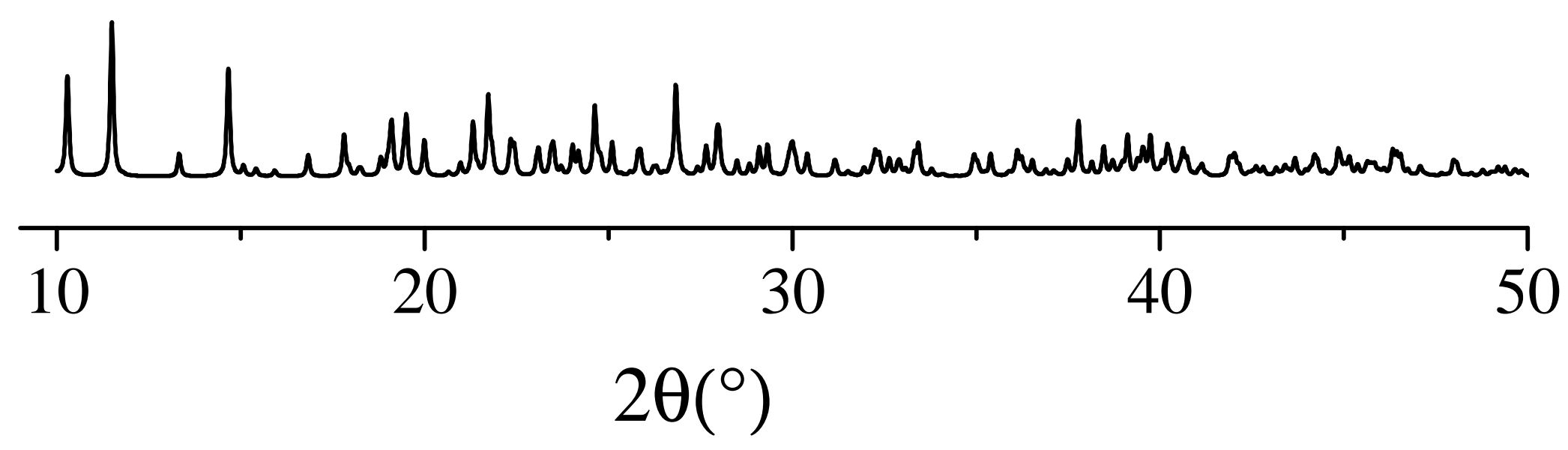


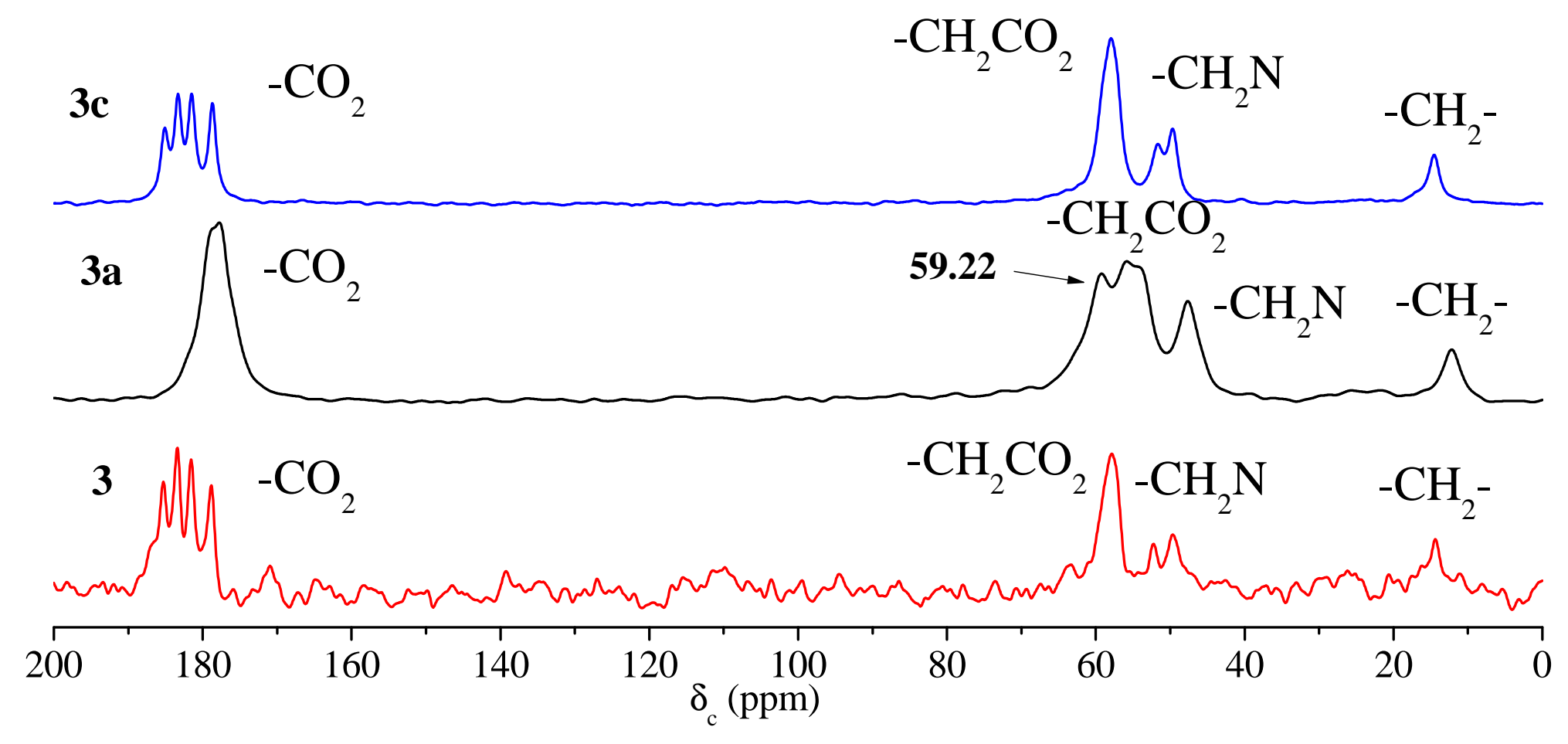


Table 1. Comparisons of the selected bond distances $(\AA)$, coordination number (C.N.) of lead ion and dentate number (D.N.) of 1,3-pdta (or edta) for $\mathbf{1} \sim \mathbf{4},\left[\mathrm{Pb}_{4}(1,3-\text { pdta })(\text { aip })_{2}\left(\mathrm{H}_{2} \mathrm{O}\right)_{4}\right]_{\mathrm{n}}(\mathbf{5}$, $\mathrm{H}_{2}$ aip = 5-aminoisophthalic acid) [38], $\mathrm{K}_{2}\left[\mathrm{~Pb}(\right.$ edta) $] \cdot 4 \mathrm{H}_{2} \mathrm{O}(\mathbf{6})[31],\left[\mathrm{Pb}_{2}(\mathrm{edta})_{2}\left(\mathrm{H}_{2} \mathrm{O}\right)_{2}\right]_{\mathrm{n}} \cdot \mathrm{nH}_{2} \mathrm{O}$ (7) [39] and $\left(\mathrm{NH}_{4}\right)_{4 \mathrm{n}}\left[\mathrm{Pb}_{2}(\mathrm{edta})_{2}\right]_{\mathrm{n}} \cdot 5 \mathrm{nH}_{2} \mathrm{O}(\mathbf{8})[40]$.

\begin{tabular}{cccccc}
\hline Entry & $\mathrm{Pb}_{\text {carboxyl }}(\mathrm{av})$ & $\mathrm{Pb}-\mathrm{N}(\mathrm{av})$ & $\mathrm{Pb}-\mathrm{O}_{\mathrm{w}}(\mathrm{av})$ & $\mathrm{C} . \mathrm{N}$. & D.N. \\
\hline $\mathbf{1}$ & $2.698(4)$ & $2.665(4)$ & --- & 8 & 7 \\
$\mathbf{2}$ & $2.729(4)$ & --- & $2.600(4)$ & 8 & 6 \\
$\mathbf{3}$ & $2.710(8)$ & $2.628(8)$ & $3.092(8)$ & $8 / 9$ & 9 \\
$\mathbf{4}$ & $2.644(5)$ & $2.599(5)$ & $2.901(5)$ & 8 & 8 \\
$\mathbf{5}$ & $2.586(5)$ & $2.701(5)$ & $2.730(5)$ & 8 & 10 \\
$\mathbf{6}$ & $2.571(8)$ & $2.561(8)$ & -- & 6 & 6 \\
$\mathbf{7}$ & $2.672(8)$ & $2.608(8)$ & $2.950(8)$ & 8 & 7 \\
$\mathbf{8}$ & $2.696(8)$ & $2.596(8)$ & -- & 8 & 8 \\
\hline
\end{tabular}


Table $2 .{ }^{13} \mathrm{C}$ NMR spectral data (in ppm) of complexes $\mathbf{1} \sim \mathbf{4}$.

\begin{tabular}{ccccc}
\hline Complexes & $-\mathrm{CH}_{2-}$ & $-\mathrm{CH}_{2} \mathrm{~N}$ & $-\mathrm{NCH}_{2} \mathrm{CO}_{2}$ & $-\mathrm{CO}_{2}$ \\
\hline 1 Solution & 26.30 & 61.74 & 63.02 & 181.78 \\
1 Solid & 25.80 & $59.45,60.84$ & $64.52,65.53$ & 178.12 \\
2 Solid & 19.45 & $52.42,56.98$ & $60.58,62.92$ & $169.87,170.80,173.40$ \\
3 Solid & 14.38 & $49.67,52.26$ & 57.87 & $178.84,181.56,183.41,185.29$ \\
4 Solid & 16.79 & 49.73 & 59.03 & $178.65,181.19$ \\
\hline
\end{tabular}


Table $3 .{ }^{13} \mathrm{C}$ NMR spectral data (in ppm) of $\mathbf{3}, \mathbf{3 a}, \mathbf{3 c}$.

\begin{tabular}{ccccc}
\hline Complexes & $-\mathrm{CH}_{2-}$ & $-\mathrm{CH}_{2} \mathrm{~N}$ & $-\mathrm{NCH}_{2} \mathrm{CO}_{2}$ & $-\mathrm{CO}_{2}$ \\
\hline $\mathbf{3}$ & 14.38 & $49.67,52.26$ & 57.87 & $178.84,181.56,183.41,185.29$ \\
3a & 12.84 & 47.64 & $53.54,55.84$ & $177.77,179.05$ \\
3c & 14.54 & $49.68,51.65$ & 57.95 & $178.70,181.50,183.32,185.09$ \\
\hline
\end{tabular}




\title{
Transformations of lead 1,3-propylenediaminetetraacetate to its MOF products for the selective adsorption of methanol
}

\author{
Jun-Wei Dai, Xing Li, Jian-Mei Zheng, Xin Dong*, Zhao-Hui Zhou*
}

Water soluble coordination polymer $\mathrm{K}_{4 n}\left[\mathrm{~Pb}_{2}(1,3-\mathrm{pdta})_{2}\right]_{\mathrm{n}} \cdot 6 \mathrm{nH}_{2} \mathrm{O}$ (1) is converted to its insoluble product $\left[\mathrm{Pb}_{2}(1,3-\mathrm{pdta})\left(\mathrm{H}_{2} \mathrm{O}\right)_{4}\right]_{n} \cdot 4 \mathrm{nH}_{2} \mathrm{O}(3)$, which contains a unique $\left(\mathrm{H}_{2} \mathrm{O}\right)_{26}$ cluster and exhibits reversible adsorption for methanol.

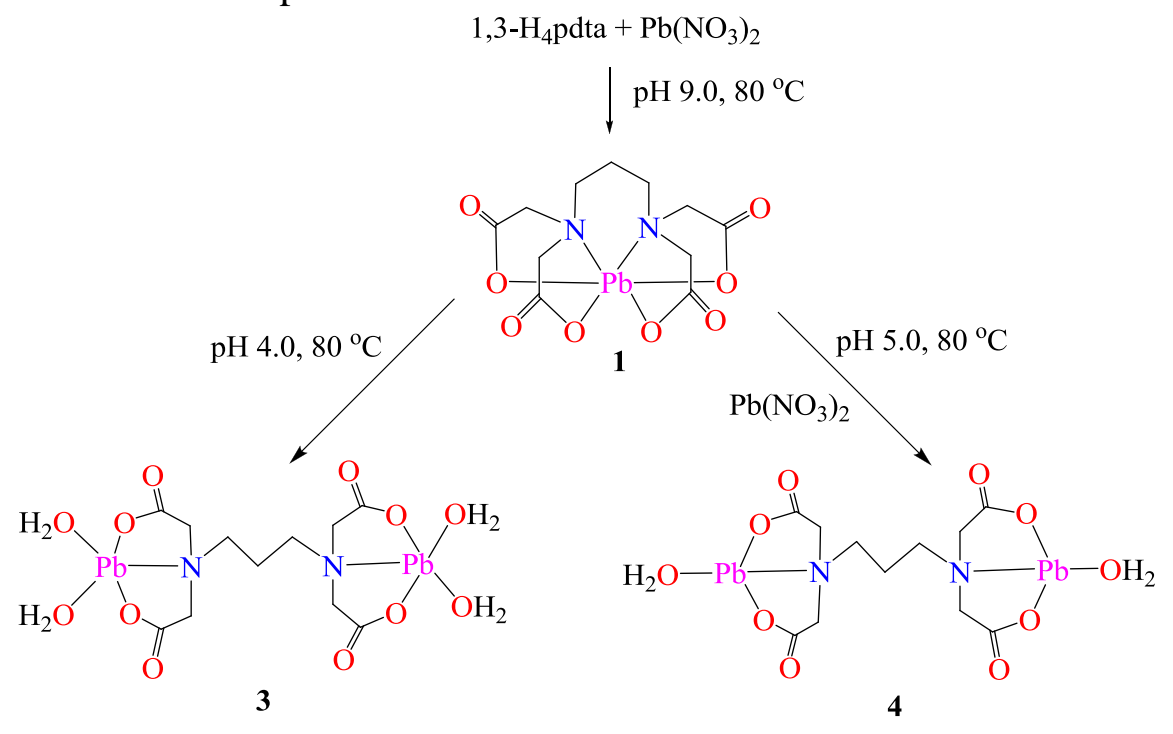

